\title{
INFLUÊNCIA DO FLORESCIMENTO DA CANA-DE-AÇÚCAR (Saccharum spp.) NA FERMENTAÇÃO ETANÓLICA
}

\author{
EDENICE APARECIDA OLIVEIRA CÉSAR FURLAN \\ Economista Doméstico
}

Orientador: Prof. Dr. JOSÉ PAULO STUPIELLO

Dissertação apresentada à Escola Superior de Agricultura "Luiz de Queiroz", da Universidade de São Paulo, para obtenção do título de Mestre em Ciências, Área de Concentração: Ciência e Tecnologia de Alimentos.

P IR A C I C A B A

Estado de São Paulo - Brasil

Fevereiro - 1995 
CATALDGACGA HA FUBLUCACAO

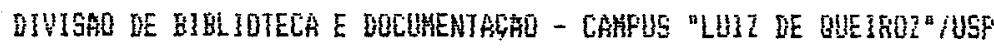

Furlan, Edenice fiparecida Dliveira Cesar

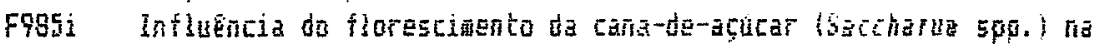

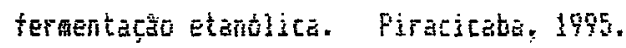

$99 \bar{y}$. ilus.

DiEs. (hestre) - ESALE

gibliografiz.

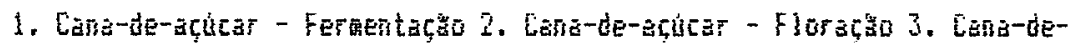
açucar - Tecnologia h. Fermentaçấu Etandica 3. Escola Superior de Agricultura Luiz de hueiroz, Firacicaba

CyD 604.122 


\section{INFLUÊNCIA DO FLORESCIMENTO DA CANA-DE-AÇÚCAR (Saccharum spp.) NA FERMENTAÇÃO ETANÓLICA}

Aprovada em: 12/04/1995

Comissão julgadora:

Prof. Dr. SILVIO ROBERTO ANDRIETTA - UNICAMP

Prof. Dr. ANTONIO JOAQUIM DE OLIVEIRA - ESALQ/USP

Prof. Dr. JOSÉ PAULO STUPIELLO - ESALQ/USP

Prof. Dr. JO\$ÉPAAULO STUPIELLO

Ofientador 
Aos meus pais, Ezequiel e Mafalda, pela minha formação profissional.

OFEREÇO 
Ao Renato, meu marido com carinho

\section{DEDICO}




\section{AGRADECIMENTOS}

À DEUS, inteligência suprema, causa primária de todas as coisas;

Ao Prof. Dr. José Paulo Stupiello pela amizade, compreensão e orientação dispensados na elaboração deste trabalho;

Aos Prof. Dr. Fernando Valadares Novaes e Prof. Dr. Luiz Eduardo Gutierrez pela colaboração;

À Escola Superior de Agricultura "Luiz de Queiroz", em especial ao Departamento de Ciência e Tecnologia Agroindustrial, pelos recursos oferecidos;

Aos funcionários do Departamento de Ciência e Tecnologia Agroindustrial pelo apoio, amizade e convivio;

À Denise A. Gonçalves Oliveira e Rosana Bessi pelo incentivo, dedicação e amizade;

À CAPES, pelo auxilio concedido em forma de bolsa de estudos;

À Bibliotecária Beatriz Helena Giongo, pela atenção prestada à revisão bibliográfica;

A todos que, direta ou indiretamente, colaboraram para a realização desta pesquisa. 


\section{SUMÁRIO}

Página

RESUMO vi

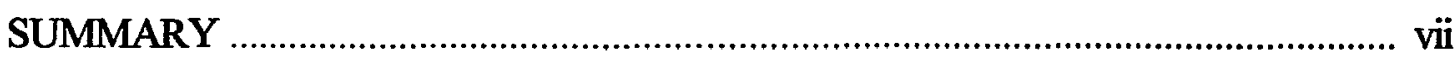

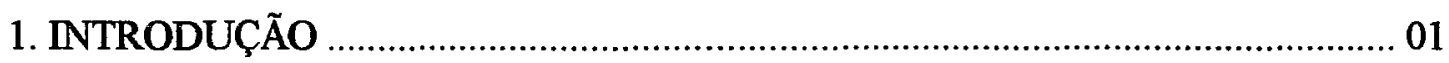

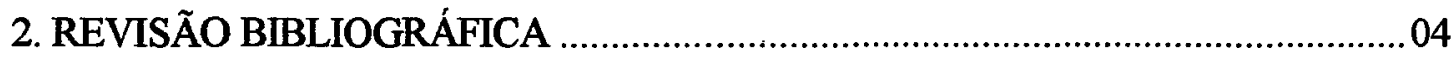

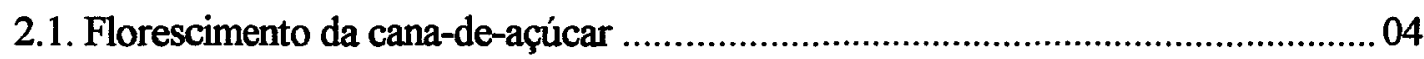

2.1.1. Influência do florescimento na qualidade agroindustrial da cana-de-açúcar . 05

2.1.2. Requisitos para o florescimento ....................................................... 18

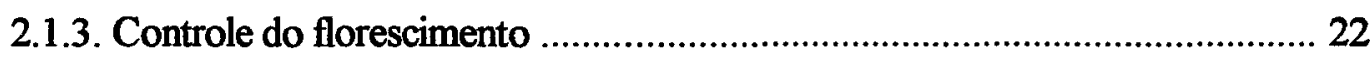

2.2. Fatores que afetam a fermentação alcoólica …………..........................................25

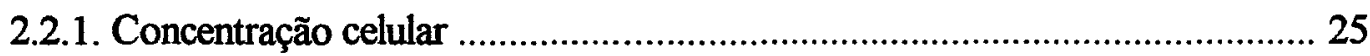

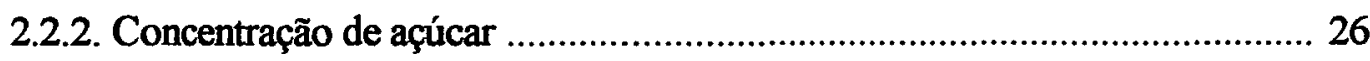

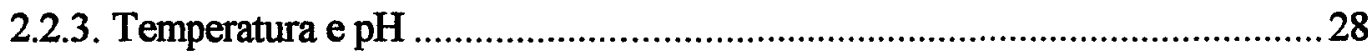

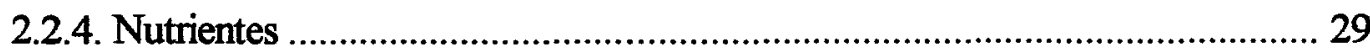

2.2.4.1. Nitrogênio …............................................................................. 29

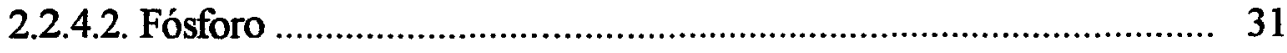

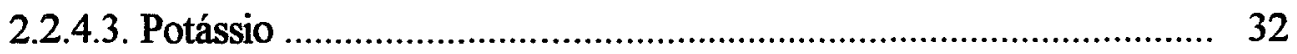

2.2.4.4. Magnésio e cálcio ................................................................... 33

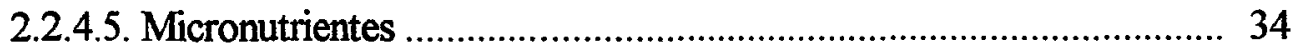


2.2.4.6. Vitaminas

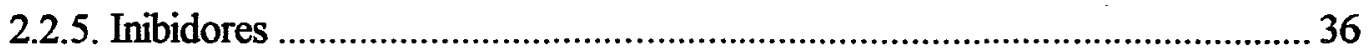

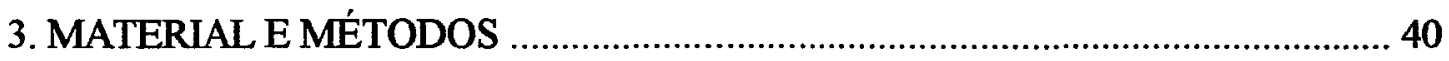

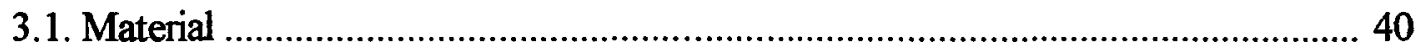

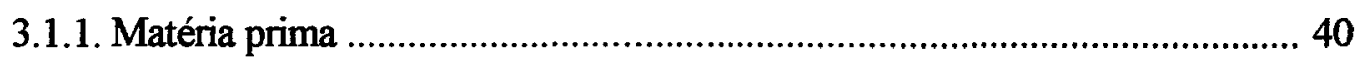

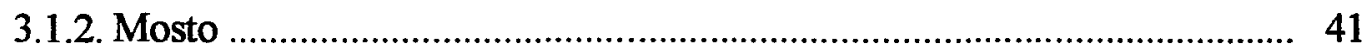

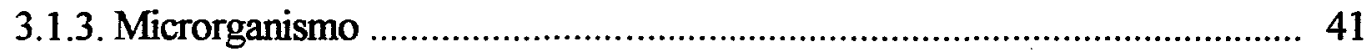

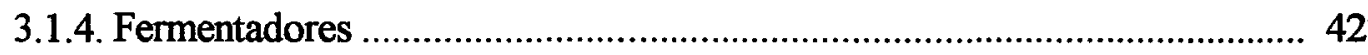

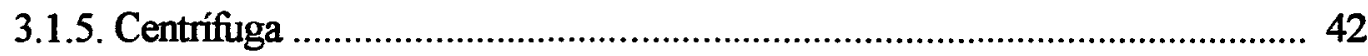

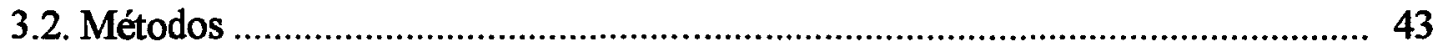

3.2.1. Açúcares redutores Totais do mosto (ART) e açúcares residuais do vinho. 43

3.2.2. Volume de células de levedura .............................................................. 43

3.2.3. Brix e Pol do caldo extraído......................................................................4

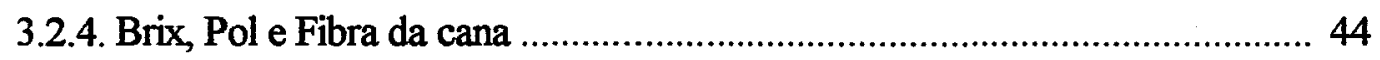

3.2.5. Teor alcoólico do fermento e vinho ........................................................ 44

3.2.6. Acidez total do mosto e acidez volátil do mosto e vinho .......................... 44

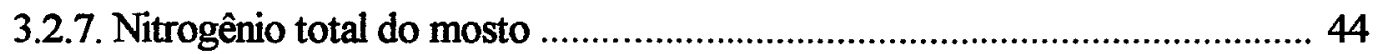

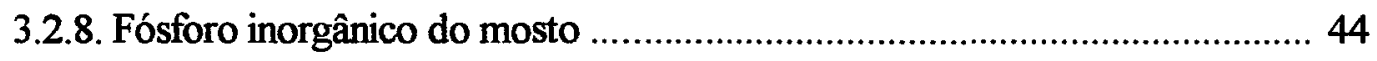

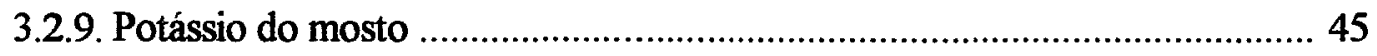

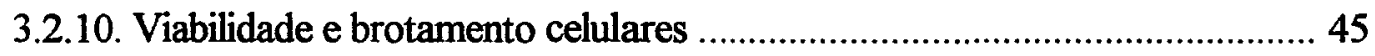

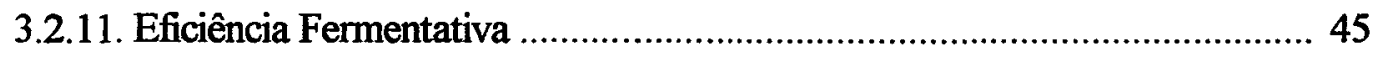

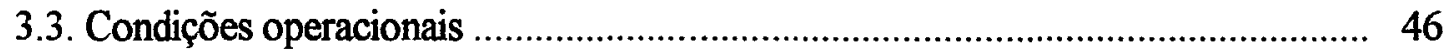




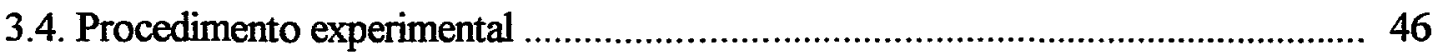

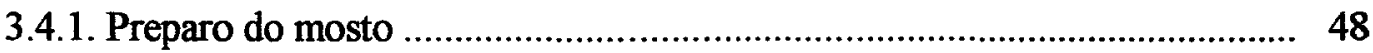

3.4.2. Preparo do Fermento .......................................................................... 48

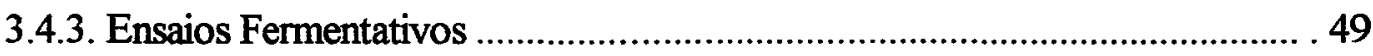

3.4.4. Recuperação do Fermento ...................................................................... 49

4. RESULTADOS E DISCUSSÃO _..................................................................... 51

4.1. Parâmetros de Qualidade dos Colmos e dos Caldos Extraídos ........................... 51

4.2. Açúcares Redutores Totais do Mosto .............................................................. 51

4.3. Acidez Total e Volátil do Mosto .................................................................... 55

4.4. Nitrogênio ……….............................................................................. 59

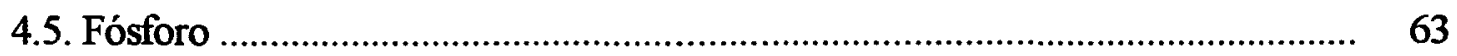

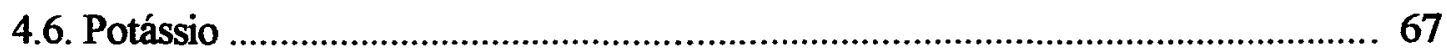

4.7. Acidez Volátil do Vinho .........................................................................

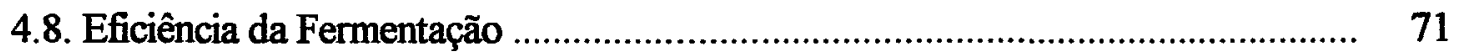

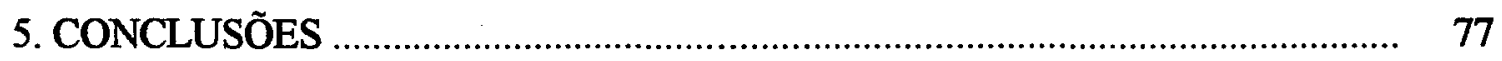

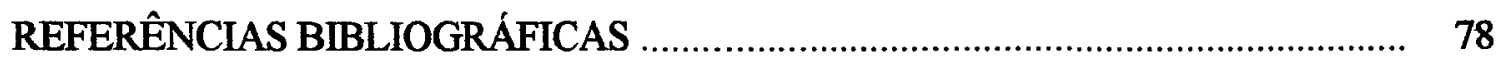




\section{LISTA DE FIGURAS}

Página

Figura 1. Fluxograma experimental

Figura 2. Médias de ART no mosto de caldo de colmos de cana-de-açúcar não florescida e florescida nos diferentes ensaios

Figura 3. Médias de Nitrogênio Total no mosto de caldo de colmos de cana-de-açúcar não florescida e florescida nos diferentes ensaios

Figura 4. Médias de Fósforo Inorgânico no mosto de caldo de colmos de cana-deaçúcar não florescida e florescida nos diferentes ensaios

Figura 5. Médias de Potássio no mosto de caldo de colmos de cana-de-açúcar não florescidas e florescidas nos diferentes ensaios

Figura 6. Médias de Eficiência Fermentativa dos ensaios com mosto de caldo de colmos de cana-de-açúcar florescida e florescida nos diferentes ensaios 


\section{LISTA DE TABELAS}

Página

Tabela 1. Determinações dos parâmetros de qualidade dos colmos e dos caldos extraídos

Tabela 2. Resultados obtidos das determinações de ART expressos em g de açúcar invertido/litro de mosto

Tabela 3. Resultados obtidos das determinações de Acidez Total expressos em mg de $\mathrm{H}_{2} \mathrm{SO}_{4} / 100 \mathrm{ml}$ de mosto e Acidez Volátil expressos em mg de $\mathrm{CH}_{3} \mathrm{COOH} /$ $100 \mathrm{ml}$ de mosto

Tabela 4. Resultados obtidos das determinações de Viabilidade e Brotamento Celular vivo

Tabela 5. Resultados obtidos das determinações de Nitrogênio Total expressos em mg de N/itro de mosto

Tabela 6. Resultados obtidos das determinações do volume de células de levedura (\%) do vinho

Tabela 7. Resultados obtidos das determinações de Fósforo Inorgânico expressos em $\mathrm{mg}$ de $\mathrm{P}_{2} \mathrm{O}_{5} /$ litro de mosto

Tabela 8. Resultados obtidos das determinações de Potássio expressos em mg de $\mathrm{K}_{2} \mathrm{O}$ / litro do mosto

Tabela 9. Resultados obtidos das determinações de Acidez Volátil expressos em mg de $\mathrm{CH}_{3} \mathrm{COOH} / 100 \mathrm{ml}$ de vinho

Tabela 10. Resultados obtidos para Eficiência Fermentativa

Tabela 11. Resultados obtidos para Grau Alcóolico do pé-de-cuba e vinho expressos $\mathrm{em} \mathrm{ml} / 100 \mathrm{ml}$

Tabela 12. Resultados obtidos das determinações de ARR expressos em g de açúcar invertido/litro do mosto 


\section{RESUMO}

\section{INFLUÊNCIA DO FLORESCIMENTO DA CANA-DE-AÇÚCAR (Saccharum spp.) NA FERMENTAÇÃO ALCÓOLICA}

\section{Autor: EDENICE APARECIDA OLIVEIRA CÉSAR FURLAN Orientador: JOSÉ PAULO STUPIELLO}

O presente trabalho objetivou a verificação da influência do processo do florescimento da cana-de-açúcar sobre o desempenho da fermentação etanólica.

As fermentações foram conduzidas com mosto de caldo de colmos de cana-de-açúcar da variedade SP 70-1143 não florescida e florescida, com reciclo do fermento, empregando fermento comercial tipo prensado.

Os parâmetros de avaliação do efeito do florescimento da cana-deaçúcar sobre a fermentação etanólica foram baseados no teores de N, P e K no mosto, ART no mosto e eficiência fermentativa.

Dos resultados obtidos, constatou-se que o mosto do caldo de colmos de cana-de-açúcar não florescida apresenta teores de N, P e K maiores que o de florescida. Quanto ao ART, o mosto, apresentou valores da mesma ordem.

Ficou depreendido também que o processo de florescimento da canade-açúcar não afetou a eficiência fermentativa. 


\section{SUMMARY}

\section{INFLUENCE OF THE FLOWERING OF THE SUGAR CANE (Saccharum spp.) IN THE ETHANOLIC FERMENTATION}

\section{Author: EDENICE APARECIDA OLIVEIRA CÉSAR FURLAN Adviser: JOSÉ PAULO STUPIELLO}

The objetive of this work was to check the effect of the flowering process of sugar cane on the performance ethanolic fermentation.

Fermentations were conducted with mash from non-flowering and flowering stalks of sugar cane, variety SP 70-1143, with yeast recycling, employing commercial pressed yeast.

The evaluation parameters of the effect of sugar cane flowering on ethanolic fermentation was based on the contents of N,P, and K and TRS contents in the mash and fermentation yield.

From the results obtained it was found that mash from non flowering sugar cane stalks showed greater N,P and $\mathrm{K}$ content than flowering stalks. Recarding TRS in the mash, there were no difference in its content among non flowering and flowering sugar cane stalks. On the other hand, TRS didn't show any variation with the flowering process.

It was also observed that the flowering process of sugar cane did not affect fermentation efficiency. 


\section{INTRODUÇÃO}

A cultura da cana-de-açúcar representa uma importante atividade econômica no Brasil, sendo uma de suas principais fontes de renda.

Em virtude da apreciável infra-estrutura agroindustrial já existente no país e do baixo custo do açúcar no mercado mundial, é que no Brasil, surgiu a decisão de produzir álcool etílico com o objetivo de equilibrar as necessidades energéticas. Desta forma, a utilização do etanol como combustível tornou-se uma realidade, o que possibilitou ao Brasil uma economia de divisas com a redução das importações de petróleo.

Hoje o setor sucroalcooleiro constitui-se um dos mais importantes da economia nacional, quer por gerar empregos, quer pela produção do açúcar destinado aos mercados interno e externo, o álcool etílico e subprodutos.

O florescimento da cana-de-açúcar é um assunto de considerável interesse para a agroindústria sucroalcooleira por várias razões. Ele é fator essencial para que se possam realizar os cruzamentos visando obtenção de novas variedades. Contudo, após a indução floral a formação de novos internódios cessa e ao mesmo tempo em algumas variedades, inicia-se o processo de chochamento do tecido fundamental. 
Este e outros fatos, bastante discutidos e em alguns aspectos controversos, podem ser responsabilizados pelos efeitos negativos do florescimento na produção agroindustrial da cana-de-açúcar (HERNANDEZ, 1965; FOGLIATA \& MORIN, 1975; SALATA \& FERREIRA, 1977). As controvérsias existentes podem ser justificadas quando se considera que os efeitos variam em função do percentual de florescimento, do desenvolvimento da planta na época da indução floral e colheita (PIRES \& MELO, 1984).

O processo de florescimento ocorre com a interação de diversos fatores no decorrer do período indutivo, como o fotoperíodo, as temperaturas máxima e mínima, a umidade do solo e a idade da planta. Tais fatores são interdependentes para a ocorrência do fenômeno (COLEMAN, 1960). Praticamente em todas as regiões onde se cultiva cana-de-açúcar no Brasil, ocorrem condições favoráveis ao florescimento, em menor ou maior grau (IAIA et al., 1985). No Estado de São Paulo, a freqüência é superior a $75 \%$.

Diversos fatores interferem e interagem na produtividade da cana-deaçúcar. Literalmente, o florescimento da cana-de-açúcar, tem se constituído num dos fatores que podem comprometer a produtividade ou produção por unidade de área, a qual pode ser representada em termos de produtividade de colmos e teor de açúcar nestes colmos, que interferem no rendimento de açúcar e/ou álcool por unidade de área.

Considerando-se que diversas variedades que florescem são altamente desejáveis sob outros aspectos agronômicos e industriais, é importante que se previna a ocorrência do florescimento em vez de substituir a variedade plantada. Como 
em escala comercial, certos métodos de controle ficam restritos, faz-se o uso de produtos químicos para tal.

O plantio de variedades floríferas de cana-de-açúcar tem aumentado no Estado de São Paulo (COLETI et al., 1984). Entre as principais variedades cultivadas em 1981 e 1982 em São Paulo, metade são floríferas, representando 61,97\% da área (RUAS et al., 1983). Assim, é de grande interesse para a agroindústria canavieira a comparação entre a cana florescida e a não florescida, tendo em vista que existem algumas controvérsias quanto aos resultados obtidos nos estudos para caracterização dos efeitos do florescimento na produtividade agroindustrial, como já citado. A isto, associado o fato de que no Brasil a obtenção de etanol para bebidas, solventes e combustível se dá pela via fermentativa e uma vez que não foram realizadas pesquisas relacionando o fenômeno do florescimento da cana à fermentação, objetiva-se neste trabalho a verificação da influência do florescimento da cana-de-açúcar no processo de fermentação etanólica. 


\section{REVISÃo BIBLIOGRÁFICA}

\subsection{Florescimento da cana-de-açúcar}

O florescimento das plantas é o produto final de uma série de efeitos cumulativos de diversas alterações metabólicas bastante sutís, que resulta na iniciação da gema floral (TANIMOTO \& NICKELL, 1967; NICKELL, 1976). É um processo absolutamente normal em certas variedades (AZZI, 1967). Contudo, esse processo que marca o ponto final do crescimento normal ou crescimento vegetativo da planta, não constitui nenhum previlégio especial de boas ou más variedades de cana (ALMEIDA et al., 1945).

Durante o período de crescimento, a gema terminal da cana vai se desenvolvendo e dando origem a novas folhas, nós e entrenós. Na ponta do colmo são produzidos hormônios que fazem alongar as células e impedem a brotação das gemas laterais. Dependendo da temperatura, umidade, nutrientes e principalmente da duração dos dias, ou seja, número de horas de luminosidade, a gema terminal deixa de formar novos gomos em certas variedades, e passa a desenvolver o botão floral dentro do cartucho. Esse fato ocorre 2 a 3 meses antes que apareça o alongamento da bainha e o "emborrachamento" que evidenciam a emissão da flecha. Quando se verifica a flor 
aberta, já se passaram 3 a 4 meses após a iniciação floral e o momento em que a cana deixou de crescer (AZZI, 1967).

A maneira mais racional de enfrentar o florescimento é admitir que ele representa o sinal de que o colmo atingiu o término do seu crescimento e não ainda a maturação, como geralmente se admite, uma vez que por maturação entende-se o estado de máxima riqueza em sacarose da cana (ALMEIDA et al., 1945).

\subsubsection{Influência do florescimento na qualidade agroindustral da cana-de- açúcar}

Para o desenvolvimento dos órgãos reprodutores e haver fecundação, as necessidades de substâncias nutritivas são consideráveis, provocando o esgotamento das reservas celulares na zona axial e a formação de uma cavidade acompanhada de diminuição da sacarose e de aumento da fibra (MIOCQUE, 1965; ALEXANDER, 1991), o que além de paralização do crescimento resulta em perda de tonelagem de cana na colheita (ARANETA JR, 1968; SALATA et al., 1982). Por outro lado, o florescimento é marcado por uma aparentemente simultânea redução na absorção pelas raizes, uma mudança interna no balanço de água, e redistribuição de nutrientes orgânicos e inorgânicos (HUMBERT, 1963). O mesmo autor relata que nitrogênio e potássio são frequentemente excretados pelo sistema radicular durante o florescimento.

De acordo com PANJE \& RAO (1961) e PANJE et al. (1969), o florescimento na cultura comercial da cana-de-açúcar é indesejável. Com a iniciação 
floral, o crescimento vegetativo do meristema apical cessa, as folhas do topo diminuem em folhas curtas. Posteriormente a porção superior da cana torna-se chochada e devido à perda da dominância apical, desenvolve brotos laterais. Finalmente há uma queda no conteúdo de açúcar (PANJE \& RAO, 1961; PANJE et al., 1969; ALEXANDER, 1973). Em essência, colmos florescidos têm perda de muita da sua habilidade para manufatura e estoque de açúcar (ALEXANDER, 1973). Contudo, segundo FOGLIATA \& MORIN (1975), durante o período normal da safra não se encontram efeitos negativos significativos do florescimento na qualidade industrial da cana-de-açúcar.

A incidência do florescimento na qualidade da cana-de-açúcar e na quantidade de açúcar obtida por hectare é de grande magnitude nos países tropicais e em muitas zonas canavieiras próximas dos trópicos, de modo que ao cessar o crescimento da gema terminal - após o florescimento - se reduz a capacidade dos colmos para produzir açúcar (FOGLIATA \& MORIN, 1975), devido ao "chochamento", principalmente na porção superior do colmo (BROWN \& CHAMBERS, 1970; FOGLIATA \& MORIN, 1975) característica esta considerada varietal (BROWN \& CHAMBERS, 1970; BARBIERI \& LOPES, 1987) e dependente das condições de umidade. Sob condições de baixa pluviosidade, as zonas chochadas confluem-se e se fazem de grande tamanho, ocupando grande parte do setor central dos internódios (FOGLIATA \& MORIN, 1975). Esta zona chochada possui pouco caldo e alto teor de fibra, o que se traduz em baixa quantidade de açúcar obtido (HUMBERT, 1963).

ALMEIDA et al. (1945) destacam como principal fato contra o florescimento, a paralização do crescimento da cana. Se esse crescimento não recomeça 
nada há que recear. Porém, quando devido à condições favoráveis de umidade, as gemas terminais das canas florescidas brotam, o açúcar armazenado é usado pela planta e o coeficiente glucósico aumenta em detrimento da quantidade do caldo. Contudo, a deterioração do caldo só se manifesta com intensidade quando o topo da cana começa a murchar e dai, morre, avermelha ou apodrece.

SALATA \& FERREIRA (1977) e FERNANDES (1984) consideram como o maior problema em relação ao florescimento, a diminuição do caldo. E como consequência disso se tem o aumento dos teores de fibra, geralmente do meio do colmo para cima, devido à formação do conhecido "isopor", mas somente em algumas variedades. Já COLETI et al. (1984), comparando o desponte convencional com o desponte total no qual se elimina os internódios "isoporizados", para se obter colmos totalmente industrializáveis, verificaram para os tipos de desponte valores de $\mathbf{7 8 , 8 8}$ e 60,23 toneladas por hectare, respectivamente, indicando que o fenômeno da "isoporização" reduz a quantidade de colmos totalmente industrializáveis em canavial intensamente florescido.

Para NUNES JR et al. (1982) o florescimento implica em grandes alterações morfo-fisiológicas da planta, sendo considerada uma característica altamente indesejável quando acompanhada de intensa "isoporização", além de poder modificar a qualidade da matéria prima sob o ponto de vista tecnológico.

O florescimento da cana-de-açúcar pode ocorrer em distintas fases de desenvolvimento desta. Assim, o artigo O FLORESCIMENTO... (1951) classifica as canas que florescem em dois grupos extremos. O primeiro compreende a cana que 
quando floresce está completamente madura, tendendo tornar-se "passada" com relativa facilidade. Neste caso, após emitir o escapo floral o caldo se enriquece de açúcares redutores em detrimento da sacarose havendo assim, uma queda do coeficiente de pureza. No segundo grupo se encontra a cana que quando floresce está completamente verde, isto é, apresenta baixo peso, pequeno teor de sacarose e elevado de redutores, sendo o coeficiente de pureza mínimo. Esta cana tem sua composição melhorada a medida que a inflorescência se desenvolve. Desta forma o florescimento deve ser encarado como um fato natural e não como um defeito das variedades. Assim, encarado por este aspecto, o florescimento não traz nenhum prejuízo ao plantador ou usineiro; desde que se efetue o corte da cana na época de seu máximo rendimento.

PIRES \& MELO (1984) verificaram em seus estudos, que quando ocorre a indução floral e a cana-de-açúcar não completou sua fase de crescimento, a ocorrência do florescimento afetará a altura do colmo diminuindo a produção, o que ocorre com maior possiblidade pelo fato do processo de "isoporização" iniciar-se ao mesmo tempo e prolongar-se até a colheita. Também CASTRO (1984), relaciona significativa redução na produção de colmos e na qualidade dos mesmos, quando o florescimento ocorre de 4 a 8 meses antes da colheita, ao comprometimento da produtividade o que pode estar associado a uma redução na sacarose produzida por unidade de cana colhida.

Muitas pesquisas apresentam resultados que dão idéia de que as canas florescidas têm melhor qualidade industrial do que canas não florescidas (FOGLIATA \& MORIN, 1975; SALATA \& FERREIRA, 1977). Assim, comparando 
colmos florescidos e não florescidos, foi concluído que os florescidos sempre apresentam maior peso de colmo, maior pol \% cana, maior porcentagem de fibra, não existindo diferenças marcantes na porcentagem de extração de caldo. (HERNANDEZ, 1965; SALATA et al., 1982).

É contudo, necessário salientar que em alguns destes estudos a comparação em geral é feita com canas de idades diferentes. Numa mesma touceira de cana, o florescimento sempre ocorre em ordem decrescente de intensidade de canas mais velhas para as mais novas, isto é, dos comos primários para os secundários e terciários. O teor de sacarose assim como o tamanho e peso, também ocorrem em escala decrescente nessa mesma ordem. Daí a razão, de que quando se comparam canas florescidas e não florescidas de um mesmo canavial se esteja incorrendo num desvio de avaliação (ALMEIDA et al., 1945; HERNANDEZ, 1965; FOGLIATA \& MORIN, 1975; BARBIERI et al., 1984; IAIA et al., 1985; BARBIERI \& LOPES, 1987). De acordo com BARBIERI et al. (1984), deve-se ainda considerar que, ao florescer, a cana praticamente perde as folhas sintetizadoras, razão porque não aumentaria o teor de sacarose, ao contrário, tenderia a utilizar o sintetizado para a formação e emissão da panícula.

Pesquisas realizadas para avaliação dos prejuízos do florescimento nas caracterísitcas tecnológicas do colmo da cana-de-açúcar, têm apresentado resultados controversos (STEHLE, 1955a e b; GOSNELL \& JULIEN, 1976; SALATA et al., 1982). Mas, STEHLE (1955b) verificou que embora existam flutuações, é real que em 
anos de intenso florescimento, a sacarose \%, o brix, a pol e a pureza são menores que em anos de florescimento menos intenso.

O fato do florescimento exercer efeitos adversos no rendimento e na qualidade das canas (LEE et al., 1985), se aplica principalmente às canas de ciclo de dois anos que nas condições do Estado de São Paulo, são plantadas em setembrooutubro, verificando-se a ocorrência do florescimento já no primeiro ano. Quanto às canas de ciclo de um ano (plantadas em setembro-outubro), relatam que o florescimento da cultura antes da colheita também pode ser prejudicial ao rendimento, uma vez que estas são colhidas no final da safra. Já em relação às canas de ano e meio (plantadas em fevereiro-março), para os autores, o florescimento não constitui problema, uma vez que sua colheita se dá geralmente, no início da safra e, neste caso, o florescimento poderia até mesmo incrementar sua maturação.

Segundo Clements \& Awada $^{1}$ citados por ALEXANDER (1973), em cana-de-açúcar com ciclo de mais de dois anos, ocorrendo florescimento no primeiro ano, poderá haver uma redução de até $20 \%$ na produtividade e que canaviais com 70 $80 \%$ de canas florescidas poderão apresentar $25 \%$ ou mais de perdas na produtividade. HUMBERT (1963) verificou que no decorrer de safras longas, isto é, de 24 meses no Havaí, apreciável florescimento no primeiro ano resulta em substancial decréscimo na

1 CLEMENTS, H.F. \& AWADA, M. Factores affeting the flowening of sugarcane. Indian Journal Sugar Cane Research Development, 8: 140-59, 1964. 
produção de açúcar. E ainda, que quando o florescimento atinge cerca de $35 \%$, pode reduzir de 2 a 3 toneladas de açúcar por acre de uma produção normal de 14 toneladas.

Em relação a brotação lateral, tem-se que após cessar a dominância apical pelo desenvolvimento da inflorescência, se persistirem condições de calor e umidade, caracaterísticas do período de crescimento, as gemas laterais superiores podem brotar formando pequenos colmos suplementares, os quais nada influem no rendimento agrícola, mas impedem que o colmo principal seque e morra. Já quando condições são favoráveis ao amadurecimento, a cana não emite a brotação lateral e continua a aumentar o seu conteúdo de sacarose, pureza e fibra depois do florescimento. Se torna então, necessário conciliar o aumento de riqueza do caldo com a diminuição da capacidade de extração decorrente do conteúdo de fibra. Existe um ponto ótimo que é característico da variedade e da região canavieira (AZZI, 1967; Long ${ }^{1}$ citado por GOSNELL \& JULIEN, 1976).

STEHLE (1955) verificou em estudos, que após cessação do desenvolvimento pelo florescimento, ocorre a inversão da molécula de sacarose em glicose e levulose, problema que intensifica-se com a formação de brotos laterais.

Investigações feitas na África do Sul, têm mostrado que o conteúdo de sacarose de canas florescidas recentemente, não diminui, mas sim aumenta (HERNANDEZ, 1965). Quando a brotação lateral toma lugar há perda de sacarose e a

\footnotetext{
${ }^{2}$ LONG, A.C. A large varietal difference in cane deterioration due to flowering. In: ANNUAL CONGRESS OF THE SOUTH AFRICAN SUGAR TECHNOLOGISTS ASSOCIATION, 50. Proceedings, 1976. p.78-81.
} 
produção cai (HERNANDEZ, 1965; HUMBERT et al., 1969), assim somente nessa ocasião tornando-se indesejável (HERNANDEZ, 1965).

Outros estudos têm mostrado que a sacarose na região do internódio que emitiu os brotos é parcialmente convertida em açúcares redutores, os quais são usados como energia para crescimento vegetativo. Como as temperaturas se elevam na primavera, mais sacarose estocada é reconvertida e usada para acelerar o crescimento vegetativo, decaindo assim, o conteúdo de sacarose recuperável, em especial na parte superior dos colmos florescidos (HUMBERT et al., 1969; FOGLIATA \& MORIN, 1975). Portanto, as canas florescidas devem ser colhidas primeiro que as não florescidas (HUMBERT et al., 1969; PANJE, 1970; FOGLIATA \& MORIN, 1975).

ALEXANDER (1973) relata que é aceito o fato de que o colmo florescido tem em geral, uma menor estrutura efetiva para a síntese e armazenamento de sacarose em relação a seu equivalente em desenvolvimento vegetativo. Enquanto que a qualidade do caldo pode, temporariamente, aumentar como uma imediata resposta ao florescimento, o subsequente crescimento de novos brotos produz, a partir de uma dada época, uma redução no açúcar armazenado na planta. É nesse aspecto que Mangelsdorf", citado por HUMBERT (1963), opina que o florescimento é uma dissipação de energia.

STEHLE (1955a e b), revisando grande número de trabalhos publicados entre 1800 e 1955 , observou que estes apontavam para resultados conflitantes,

${ }^{1}$ MANGELSDORF, A.J. Sugar cane breeding: the retrospec and in prospect. Proceedings 9 th. CONGRESS OF THE INTERNATIONAL SOCIETY OF SUGAR CANE TECHNOLOGISTS, I, 560-75, 1956. 
mas a conclusão geral foi que o florescimento resultou em um aumento de açúcar até se estabelecer deterioração causada por seca do topo do colmo onde foi inadequada a brotação lateral.

Parece que o efeito do florescimento na produção e qualidade é complexo e é evidente que o intervalo entre o florescimento e a colheita da cana, a época de indução floral, as condições climáticas prevalescentes após florescência, e o número de brotos laterais e taxa de desenvolvimento dos mesmos podem representar importantes funções determinando o efeito do florescimento na qualidade e produção (GOSNELL \& JULIEN, 1976).

Analisando o comportamento de canas florescidas e não florescidas, pode-se verificar claramente que as características agroindustriais da cana caíram com o decorrer do processo de florescimento (BARBIERI et al., 1984).

HERNANDEZ (1965) e FOGLIATA \& MORIN (1975), em pesquisas encontraram que desde a iniciação floral até o fim da primavera, as canas florescidas apresentam maiores teores de pureza, pol e rendimento industrial. Porém, FOGLIATA \& MORIN (1975) observaram que a partir desta data, com o aumento da temperatura do ar, grande parte da sacarose armazenada é invertida e usada para crescimento vegetativo dos brotos laterais, diminuindo assim o teor de açúcar recuperável, principalmente na parte superior dos colmos florescidos.

JULIEN et al. (1977) conduziram estudos nas Ilhas Maurício com a variedade M 351/5 e mostraram que a pol da cana dos colmos florescidos crescem do 
início ao final da safra, enquanto Bendigiri et al. ${ }^{1}$, citado por PIRES et al. (1987) em estudos sobre os efeitos do florescimento na variedade Co 740, na Índia, observaram melhoria da qualidade do caldo durante os três primeiros meses após a indução floral e uma posteiror queda no peso médio dos colmos. Em São Paulo, IAIA et al (1985) estudaram o efeito do florescimento sobre as variedades $\mathrm{Na}$ 56-79, SP 70-1143 e IAC 48-65 e concluíram que apesar de ter havido alterações morfológicas e tecnológicas, estas não foram tão drásticas e, pelo contrário, foram benéficas em algumas épocas de colheita, quando considerados ciclos de ano e meio.

Na região Nordeste do Brasil, é prática usualmente adotada por produtores, a colheita da cana-de-açúcar florescida logo no início da safra (PIRES et al., 1987) o que é recomendado por BARBIERI et al. (1984) para as regiões Centro-Sul. Porém, em estudos para a verificação da influência da época de colheita na qualidade da variedade de cana-de-açúcar RB 72454 florescida, PIRES et al. (1987) concluíram a partir dos dados obtidos, não ter havido uma vantagem na colheita da cana florescida já no início da safra. Pelo contrário, os resultados obtidos mostraram que um pequeno retardamento na colheita da variedade estudada florescida não provocou queda na produção de açúcar por área. Além disso, o retardamento do corte faz com que os colmos atravessem o período indutivo sem terem atingido a maturidade necessária, o

1 BENDIGIRI, A.V.; JADHAV, M.B.; HAPASE, D.G.; PATIL, S.S. Studies on effect of flowering and delayed harvesting in sugarcane variety - Co 740. In: ANNUAL CONVENTION OF THE SUGAR TECHNOLOGISTS ASSOCIATION OF INDIA, 44 . Proceedings. p.132-6, 1980 . 
que, segundo PIRES \& MELO (1984), poderá contribuir para o controle do florescimento nos ciclos subsequentes.

Através de pesquisas feitas em Piracicaba - SP, com variedade de florescimento precoce e maturação tardia, AZZI (1967) verificou um ganho industrial de 50 a $80 \%$ quando se colhia a cana depois de 3 a 4 meses, a contar do início do aparecimento da inflorescência. Somente depois desse período, quando a flecha começa a secar, inicia-se a deterioração do caldo. Assim o florescimento assume importância econômica toda vez que se apresenta em cana jovem, antes de alcançar o seu completo desenvolvimento. Contudo, para ARANETA (1968), se a colheita for feita em um período muito após a iniciação floral, a diminuição da produção, ou seja, da porcentagem de sacarose e queda do peso da cana torna-se especialmente séria, pois do mesmo modo que o florescimento pode levar a um amadurecimento prematuro, poderá causar também um declínio precoce na produção.

MARTIN-LEAKE (1946) afirma que a importância econômica do florescimento da cana está relacionada ao efeito que exerce na tonelagem e qualidade do caldo. Perda de peso começa poucas semanas após a indução floral, e, onde a umidade É abundante, pode continuar até o ponto onde $50 \%$ do potencial de tonelagem é perdido. Tanto o declínio da qualidade como o da tonelagem, é diminuído sob condições de seca. Mudanças adicionais que são mais pronunciadas no florescimento da cana-de-açúcar, incluem uma menor porcentagem de açúcares redutores, maior conteúdo de cinzas e temporário aumento da pureza do caldo seguido por diminuição desta. 
Segundo HUMBERT et al. (1969), a redução do florescimento é extremamente desejável, uma vez que cana não florescida tem um alto potencial de produção e práticas agrícolas podem ser modificadas para assegurar produções ótimas e lucro. Quando cana floresce não é possível melhorar práticas culturais para um mesmo ponto ótimo como com variedades que não florescem, pois o florescimento coloca um limite na produção da cana.

Colmos maduros impedidos de florescer continuam crescendo, produzindo e armazenando açúcar (HUMBERT et al., 1969). HERNANDEZ (1965) realizou uma pesquisa detalhada sobre o efeito do florescimento na fibra \% cana, extração do caldo \% cana, porcentagem de sacarose no caldo, produção de açúcar e peso da cana. Estudos comparativos foram feitos na iniciação da formação da flor, depois em colmos florescidos com flores amadurecidas, e finalmente nos colmos florescidos com flores velhas. As diferenças entre canas florescidas e não florescidas aparecem em vários estágios do desenvolvimento do florescimento e são intensificadas em colmos com flores velhas.

Em cana florecida os internódios superiores contêm mais fibra. $\mathrm{O}$ chochamento para muitas variedades que florescem decresce nos internódios mais abaixo (HUMBERT et al., 1969). Em canas com flores velhas, HERNANDEZ (1965) observou que a porcentagem total de fibra na cana florescida é $4,03 \%$ maior que na não florescida, sendo que nos primeiros seis internódios a porcentagem de fibra é $14,04 \%$ maior na cana florescida. A porcentagem de fibra do sétimo internódio para baixo é praticamente a mesma em ambas. Devido a esse grande conteúdo de fibra nos 6 
internódios superiores da cana com flores maduras, a extração de caldo \% cana é $17 \%$ menor. Em canas florescidas o conteúdo de dextrose excede o de levulose e consequentemente a sacarose aparente é maior do que o valor exato. Assim, as medidas aparente e real de sacarose do caldo extraído, são respectivamente $5,54 \%$ e $2,89 \%$ maiores em canas florescidas.

O autor ainda compara a pureza dos caldos de canas florescidas e não florescidas e mostra que nos seis internódios superiores a pureza aparente do caldo das canas florescidas é $0,4 \%$ maior que das não florecidas. O caldo do sétimo internódio para baixo de canas florescidas apresenta pureza aparente 3,62\% menor dọ que da não florescida. Nos seis internódios superiores, a pureza real do caldo de canas florescidas é 2,09\% menor e em internódios inferiores, $5,23 \%$ menor do que o caldo de canas não florescidas.

Ainda, de acordo com HERNANDEZ (1965), pelo fato de existir mais fibra na cana florescida, o rendimento da extração é cerca de $5 \%$ menor. E, este decrécimo deve ser considerado no cálculo da produção real. Desta forma a produção real total da cana florescida, que e $\mathbf{0 , 9 8 \%}$ maior que da não florescida, tem uma queda de $4,02 \%$.

FOGLIATA \& MORIN (1975), verificando a qualidade industrial de cana-de-açúcar florescida, obtiveram como média final um valor aproximadamente 9,0\% mais de fibra nas canas florescidas e com uma tendência em aumentar com o avanço do verão e idade da cana. Com o mesmo objetivo, os autores realizaram um experimento em Tucumán, Argentina, no qual observaram que a cana florescida sempre 
teve mais fibra que a não florescida. Em média geral foi 14,55\% e 13,81\%, respectivamente.

Além de perdas absolutas de produção devido a cessação do crescimento terminal nos colmos de cana que florescem em uma idade jovem, outros fatores são responsáveis por perdas com o florescimento (GOSNELL \& JULIEN, 1976). Em regiōes nas quais o florescimento é considerado indesejável, o problema poderia ser solucionado através do plantio de variedades que apresentassem certa resistência a esse fenômeno. Entretanto, diversas variedades que apresentam florescimento intenso, são altamente desejáveis sob outros aspectos agronômicos e industriais. Nestes casos, haveria um interesse maior em se previnir o florescimento do que em substituir a variedade plantada (ALEXANDER, 1973).Embora ocorram diferenças varietais, canas florescidas geralmente desenvolvem uma considerável quantidade de "medula" com correspondentes perdas no caldo \% cana. Canas florescidas invariavelmente desenvolvem um grande conteúdo de fibra que resulta em menor aceitação das mesmas pela usina e perdas na extração. Pode ser notado contudo, que uma produção grande de bagaço é de considerável vantagem para produção de vapor, principalmente onde há um alto requerimento de energia (GOSNELL \& JULIEN, 1976).

\subsubsection{Requisitos para o florescimento}

O fenômeno do florescimento é normalmente dependente das variações climatícas (ALMEIDA et al., 1945; CASTRO, 1984; MACHADO JR, 1987). 
Ele geralmente ocorre em cada planta e em cada lugar, em uma determinada época do ano. Como a cana-de-açúcar é cultivada sob as mais variáveis condições climáticas do mundo inteiro, encontra-se grandes variações nas causas ligadas ao florescimento (ALMEIDA et al., 1945).

As causas que provocam o florescimento de cana-de-açúcar são muito complexas, porque apresentam uma relação de fatores diferentes para cada clima. Os climas equatoriais possuem todas as características para o florescimento de todas as variedades de cana em geral. Mas, nas zonas subtropicais, a ausência de um ou outro desses fatores, que acompanham as variações climáticas durante anos seguidos, permite o estudo de diversos fenômenos (MIOCQUE, 1965). Para o autor, o princípio geral é baseado no desiquilibrio hídrico entre a disponibilidade de umidade e a água gasta pela evapotranspiração das folhas. Este desiquilibrio provoca uma autodefesa da planta, que reage com a formação de hormônios vegetais, auxinas, para emissão dos órgãos reprodutivos, visando a continuação da espécie.

O florescimento da cana-de-açúcar é primeiramente um fenômeno fotoperiódico, mas outros fatores interno e externos tais como temperatura ambiente, tipo do solo, umidade do solo, latitude (ALMEIDA et al., 1945; COLEMAN, 1960; ALLAM et al., 1977) e altitude, variedade e idade da cultura, sanidade da cultura, tratos culturais, adubação, época de plantio (ALMEIDA et al., 1945), maturidade para florescer, umidade relativa, qualidade da luz e relações entre auxinas (COLEMAN, 1960; ALLAM et al., 1968). Estudos de CLEMENTS \& AWADA (1967), COLEMAN (1969) e ALEXANDER (1973) observam os efeitos de muitos desses fatores no 
florescimento da cana-de-açúcar. COLEMAN (1969) indicou que os limites específicos de cada um destes fatores devem ocorrer simultaneamente para ocorrer o florescimento. De acordo com FAUCONNIER \& BASSEREAU (1975), o estímulo para transformar a gema apical vegetativa do colmo em gema floral reprodutiva requer para ser suficiente, um certo número de condições as quais devem ser reproduzidas durante certo número de dias para serem eficazes. Tais condições são: duração do dia próximo a 12,5 horas, temperatura mínima superior a $18^{\circ} \mathrm{C}$, umidade suficiente a planta, perfeito estado vegetativo do sistema foliar.

A noite com duração de 11,5 a 12,00 horas, é favorável a indução do florescimento. No Hemisfério Sul, isto ocorre entre fevereiro e março e o florescimento aparece de abril a julho; no Hemisfério Norte, a indução se dá em agostooutubro e o florescimento de outubro a janeiro. Em regiões próximas ao Equador, como as Antilhas, a cana pode florescer duas vezes num mesmo ano, devido à ocorrência de dois períodos em que o comprimento do dia é favorável à diferenciação floral. Quanto mais distante do Equador, o florescimento diminui devido às variações do comprimento do dia (MACHADO JR, 1987).

A cana-de-açúcar é considerada sensível a luminosidade para florescer, sendo uma planta que somente floresce quando submetida a dias com comprimentos inferiores a um fotoperíodo crítico, sendo portanto, uma planta de dias curtos. O fotoperíodo ideal parece ser de 12,5 horas, sendo que a maioria dos cultivares respondem a este fotoperíodo nas diferentes regiōes do mundo (CASTRO, 1984). O 
fornecimento de um fotoperíodo adequado resultou em um sucesso notável na indução do florescimento (EVANS \& BATES, 1966).

As variedades de cana apresentam não só uma capacidade de florescer muito diferente como também o tempo de florescimento. $O$ hábito de florescer é um caráter auxiliar de certa importância na classificação das variedades. Em relação à idade da cultura, parece que a cana planta ou de primeiro corte apresenta menor frequência ao florescimento que a soqueira (ALMEIDA et al., 1945; MACHADO JR, 1987). Pode ser necessária uma maturidade para florescer antes da indução floral, representada por certo número de internódios expostos (ARCENEAUX, 1967; COLEMAN, 1960) e um número de folhas, no período fotoindutivo (COLEMAN, 1969). Sendo que o período fotoindutivo geralmente coincide com o desenvolvimento de 2 a 4 internódio maduros na base do colmo (CLEMENTS \& AWADA, 1967; COLEMAN, 1969). Já o fator umidade do solo, deve ser avaliado admitindo que a intensidade da precipitação anual e a sua distribuição é que tem marcada e direta influência no florescimento (ALMEIDA et al, 1945). Segundo EVANS \& BATES (1966) a influência da água na primavera, foi cosiderada uma influência na antecipação e intensidade do florescimento na Guiana. ALLAM et al. (1977) verificaram que a baixa retensão de umidade do solo e baixo nível de nitrogênio no mesmo durante a iniciação floral, tem um efeito sinérgico na indução floral.

Em solos mais fracos, a tendência ao florescimento é maior, pois uma disponibilidade abundante e imediata de nitrogênio e fósforo promoveria um crescimento rigoroso e a planta atrasaria a passagem do estágio vegetativo para 0 
reprodutivo, tendo a possibilidade de redução de florescimento. O plantio de coleções em covas, favorece o desenvolvimento das touceiras pela menor competição por água, luz e nutrientes, proporcionando também um maior florescimento (MACHADO JR, 1987).

Em experimentos realizados por PEREIRA et al. (1986), com a variedade NA 56-79 cultivada em condições de campo em Araras (SP), verificou-se que é possível prever-se o florescimento, com base na ocorrência de temperaturas máxima e mínima durante o fotoperíodo indutivo. E que a frequência de noites com temperatura $\geq 18^{\circ} \mathrm{C}$ e dias com temperatura máxima $\leq 31^{\circ} \mathrm{C}$ discriminam anos com e sem florescimento, sendo que, durante o período indutivo os anos com florescimento têm, em geral, temperaturas mínimas maiores, temperaturas máximas menores, mais chuva e maior frequência de dias chuvosos.

A latitude a altitude têm uma influência decisiva no florescimento, devido às mudanças que elas causam nas condições climáticas (umidade, calor, luz, ventos etc) (ALMEIDA et al., 1945).

\subsubsection{Controle do florescimento}

Que o florescimento diminui a qualidade da cana é talvez melhor mostrado pelo aumento da sacarose obtido quando o florescimento tem sido previnido por um ou outro meio (ALEXANDER, 1973). Assim, maior produção de açúcar tem sido registrado através do controle do florescimento por interrupção do período escuro 
(PANJE et al., 1969; CASTRO, 1984), desfolha (PANJE et al., 1969) e por pulverização com produtos químicos (TANIMOTO \& NICKELL, 1967; HUMBERT et al., 1969).

O florescimento de cana-de-açúcar, primariamente uma resposta ao fotoperíodo é condicionado por fatores complementares, os quais independentemente ou conjuntamente podem reduzir grandemente a extensão do florescimento e em casos extremos, inibi-lo inteiramente. Temperatura e umidade são condições especialmente importantes (ARCENEAUX, 1967).

Númerosos estudos tem sido realizados numa tentativa de se evitar o florescimento. Como meios eficientes de controle podem-se salientar, iluminação noturna (interrupção da noite), controle de temperatura com baixas temperaturas, poda do cartucho foliar e de folhas, suspensão do fornecimento de água e aplicação de produtos químicos (TANIMOTO \& NICKELL, 1967; NICKELL, 1976; CASTRO, 1984; PIRES \& MELO, 1984). Experimentos no Havai mostraram que a inibição floral através de quebra da noite, pulverização com produtos químicos ou indução de estresse hídrico (cessando a irrigação) podem levar a aumentos de 10 a $20 \%$ na produção, sob condições indutoras de alta florescência. Sob condições de campo, a média de ganhos na produção através da supressão da florescência foi da ordem de $15 \%$, o equivalente a 3,2 toneladas de sacarose por hectare (CASTRO, 1984).

Estudos realizados por PANJE \& RAO (1961) e PANJE et al. (1969) concluiram que em cana-de-açúcar as folhas jovens expandidas do meristema apical, constituem o principal orgão sensitivo para a percepção dos estímulos 
fotoperiódicos e que o florescimento da cana pode ser prevenido por remoção desse em época apropriada, o que está de acordo com o relato feito por PANJE (1970), o qual observou ainda a ocorrência de aumento na produção e também no conteúdo de açúcar do caldo.

A irrigação das culturas de cana-de-açúcar pode controlar o florescimento (HUMBERT, 1963; MIOCQUE, 1965; HUMBERT et al., 1969). No México foram realizados experimentos nos quais o controle do florescimento da cana foi feito através da supressão da água de irrigação. Verificou-se que uma alta porcentagem de colmos que receberam uma irrigação normal floresceram, enquanto que as que passaram por um estresse hídrico tiveram significativamente um menor florescimento (HUMBERT et al., 1969). Contudo, somente quando a irrigação é feita para regular a umidade apenas acima do ponto de murchamento poderá ser considerado um método efetivo de controle, pois quando a umidade é mantida no limite da capacidade de campo, ela pode ocasionar o apodrecimento das raízes e produzir um efeito contrário (MIOCQUE, 1965).

Segundo MIOCQUE (1965), o aumento das adubações fortemente nitrogenadas, evitam o florescimento, o que também foi verificado por AZZI (1967) e PIRES \& MELO (1984). A prática da adubação nitrogenada é comum na região do nordeste brasileiro, o que facilita o uso deste método, mas a viabilização desta prática depende do conhecimento das dosagens e épocas de aplicação, tanto do aspecto do controle do florescimento como dos seus possíveis efeitos na produção agrícola (PIRES \& MELO, 1984). 
Como a temperatura não é passivel de controle no campo, o corte de folhas e iluminação noturna não são viáveis em escala comercial e a suspensão do fornecimento de água fica necessariamente restrito às áreas irrigadas, sendo que a ocorrência de chuva durante o período de controle anularia esse método, a utilização de produtos químicos tem-se tornado, eventualmente a prática padrão para o controle do florescimento (AZZI, 1967; NICKELL, 1976; CASTRO, 1984; LEE et al.,1985).

Na realidade, constatou-se que qualquer recurso que resulte num atraso do desenvolvimento normal da planta, tenderá a suprimir o florescimento, se aplicado no período crítico de sua indução (ALEXANDER, 1973).

A capacidade de evitar o florescimento é extremamente importante na agricultura quando a florescência causa decréscimos nos beneficios econômicos. Assim, para aumentar a produção da cana de açúcar é comercialmente viável inibir o florescimento desta cultura (CASTRO, 1984).

\subsection{Fatores que afetam a fermentação alcoбlica}

\subsubsection{Concentração celular}

As leveduras são os principais organismos atualmente utilizados para a produção de etanol em escala industrial com as linhagens de Saccharomyces, Schizosaccharomyces e Kluyveromyces (GUTIERREZ, 1994). 
Em meio anaeróbico, as leveduras convertem pela via glicolítica (Embden Meyerhof) a glucose em etanol e $\mathrm{CO}_{2}$ com liberação de energia. A indústria seleciona as linhagens de leveduras a serem utilizadas por alta taxa de fermentação, alta eficiência, tolerância a açúcar e etanol, baixo $\mathrm{pH}$ e alta temperatura de fermentação (MAIORELLA, 1985).

Segundo PANCHAL \& TAVARES (1990), para fermentação rápida nas condições industriais de fabricação do etanol combustível, é permitida altas concentrações de inóculo utilizadas e consequentemente altas temperaturas.

A manutenção da alta concentração celular é permitida pela recirculação da levedura e a maior eficiência obtida é decorrente de um menor consumo de açúcar utilizado para a formação de células (CASEY et al., 1984; AMORIN et al., 1985), que segundo as condições de fermentação pode desviar de 2 a $10 \%$ do açúcar total (STUPIELLO \& HORII, 1982). As altas concentrações iniciais de células ocasionam menor crescimento (NAGODAWITHANA et al., 1974), permitindo maiores taxas de produção de etanol (CACHOT et al., 1991), enquanto que a remoção de células determina queda na eficiência fermentativa (DE MARTIN \& OLIVEIRA, 1981).

\subsubsection{Concentração de açúcar}

As leveduras tem seu crescimento influenciado pelo aumento da concentração do substrato. WADA et al. (1981) observaram que o aumento de $10 \%$ para 25\% de glucose no meio reduziu o crescimento de células de Saccharomyces cerevisiae 
imobilizada e que a alimentação parcelada do meio com glucose reduziu o efeito inibitório.

NAGODAWITHANA et al. (1974) verificam que a adição de 15\% do açúcar seguida depois de uma hora por mais de $10 \%$, ou então adições de $2,5 \%$ ou $5,0 \%$ produziram fermentações com maior viabilidade. Essa observação vem de encontro ao recomendado por KENYON et al. (1986) de se alimentar as dornas de fermentação nas destilarias o mais lentamente possível.

Aumentando-se a concentração de sacarose do meio fermentativo ocorre aumento da produção de glicerol (GUTIERREZ, 1994). Segundo HOMMES (1966), com o aumento da concentração de acúcar no meio, ocorreu aumento da atividade de enzimas glicolíticas e redução da atividade de desidrogenase alcoólica. Assim, o NAD oxidado seria regenerado com maior intensidade pela desidrogenase de glicerol-fosfato (GUTIERREZ, 1994).

Também foi verificado por GUTIERREZ (1994), que quando se utiliza grandes concentrações de sacarose no meio, deve-se realizar a adição do meio fermentativo gradualmente, com o objetivo de reduzir a formação de glicerol. Segundo o autor, este fato poderia ser explicado pela menor atividade de enzimas que conduzem a formação de glicerol, como por exemplo, a piruvato carboxilase, e maior atividade de enzimas que provocam menor formação de glicerol como a piruvato descarboxilase e a desidrogenase alcoólica. 


\subsubsection{Temperatura e pH}

Em estudos para verificação da viabilidade de Saccharomyces cerevisiae na fermentação, NAGODAWITHANA et al. (1974) observaram que com a elevação da temperatura ocorria a redução do tempo de fermentação e o aumento na taxa de morte celular. Temperaturas ótimas para crescimento de células de levedura foram relatadas por WALSH \& MARTIN (1977), sendo que para Saccharomyces cerevisiae esta variou entre $30-35^{\circ} \mathrm{C}$ e para $S$. uvarum entre $26,8-30,4^{\circ} \mathrm{C}$.

Segundo GUTIERREZ (1989), o aumento da temperatura de fermentação de $12^{\circ} \mathrm{C}$ para $35^{\circ} \mathrm{C}$ determina menor formação de etanol e redução do crescimento celular quando a temperatura aumentou de $26^{\circ} \mathrm{C}$ para $35^{\circ} \mathrm{C}$. E ainda, que o aumento da temperatura também resulta em maior formação de glicerol.

Quanto maior a temperatura de fermentação, mais alta a concentração intracelular de etanol devido a maior resistência de difusão através da parede celular (NAVARRO \& DURAND, 1978).

A menor formação de etanol associada ao menor crescimento da levedura a $35^{\circ} \mathrm{C}$ também poderia ser explicado por uma maior excreção de aminoácidos (LEWIS \& PHAFF, 1964) e de ácido pirúvico (LAFON-LAFOURCADE \& PEYNALD, 1966).

Com a utilização das leveduras Saccharomyces cerevisiae (M-300A), S. cerevisiae (panificação) e S. uvarum (IZ-1904), GUTIERREZ (1989) observou que o efeito do pH não foi sentido para a produção de etanol nas leveduras M-300-A e 
IZ-1904, porém, para a levedura de panificação ocorreu a redução no teor alcóolico do vinho quando o $\mathrm{pH}$ passou de 3,0 para 4,5, o que poderia ser explicado pelo maior crescimento verificado. Ainda, segundo o autor, a levedura M-300-A parece apresentar maior resistência a pH baixo do que as demais.

\subsubsection{Nutrientes}

\subsubsection{Nitrogênio}

O nitrogênio é um elemento importante, pois ele entra como constituinte de várias susbstâncias orgânicas presentes na levedura (WHITE, 1954).

A presença de nitrogênio na forma de aminoácidos no meio de fermentação aumenta a conversão de açúcar em etanol como desmonstrado por HARRISON \& GRAHAM (1970). Os mesmos autores relataram que em meio deficiente em nitrogênio, ocorreu fermentação mais lenta, demonstrando que quanto maior o teor de aminoácidos menor o tempo de fermentação.

Aumentando a disponibilidade (PICKERELL, 1986) de nitrogênio na forma de aminoácidos, vai ocorrer maior produção de etanol, ocorrendo também aumento considerável no crescimento (GUTIERREZ, 1989). Isto, segundo GUTIERREZ (1994), pode ser justificado pelo fato de que a levedura não necessita desviar carbono para a síntese de aminoácidos. Se o nitrogênio estiver na forma amoniacal vai ocorrer menor formação de etanol, pela mesma razão. 
Maiores valores de eficiência, produtividade e rendimento no processo de fermentação alcóolica, além de resultados mais elevados da viabilidade celular, são obtidos pela contínua adição de nitrogênio (RIBEIRO et al., 1987). A eficiência da fermentação alcóolica com melaço da cana-de-açúcar na Índia, foi aumentando com a adição de uréia e fosfato (DHAMIJA et al., 1986).

Havendo uma limitação de nitrogênio, o crescimento das células de levedura é reduzido, e , como consequência, uma significativa parcela de glicose poderá ser convertida em glicogênio, sendo que na ausência de nitrogênio a velocidade da fermentação diminui, aumentando consequentemente o tempo de fermentação e diminuindo a produtividade (STUPIELLO \& HORII, 1981).

GEERLIGS (1924) afirma que os valores de nitrogênio no caldo de cana-de-açúcar variam entre 0,018 e $0,062 \%$, tendo como média $0,036 \%$. WIGGINS (1969) encontrou como valor médio $0,018 \mathrm{~g}$ de nitrogênio por $100 \mathrm{ml}$ de caldo. MAHAMUNI et al. (1973) encontraram teores de nitrogênio, expressos em termos de miligrama de nitrogênio total por $100 \mathrm{ml}$ de caldo, variando de 28,22 a 37,37 . Já AMORIM (1985) cita como teor ideal de nitrogênio total no mosto para a fermentação alcoolica, a faixa de 500 a $600 \mathrm{ppm}$.

Segundo AMORIM (1977), o íon $\mathrm{NH}_{4}^{+}$é efetor positivo da fosfofrutoquinase e aldolase, acelerando a produção de piruvato e consequentemente de etanol em anaerobiose. Assim, não é aconselhado trabalhar com teores de nitrogênio assimilável muito baixos, porque além do tempo da fermentação completa ser mais longo, a multiplicação da levedura será muito baixa. 
É recomendado por MAIORELLA et al. (1981) para o preparo de meio de fermentação, uma quantidade de 1.100 ppm de nitrogênio amoniacal, enquanto em MAIORELLA (1985) há a citação de 750 ppm de nitrogênio amoniacal. Já RAINBOW (1970) recomendou 848 ppm de nitrogênio amoniacal.

Em comparação entre nitrogênio amoniacal e uréia em relação a produção de etanol, crescimento e glicerol produzido, não houve diferenças significativas entre as duas fontes de nitrogênio. Assim pode-se recomendar tanto sulfato de amônio como uréia para suplementar mostos com nitrogênio (GUTIERREZ, 1994).

\subsubsection{Fosforo}

O fósforo é um elemento essencial ao crescimento das leveduras e à fermentação (AMORIM, 1977; ZAGO, 1982). É importante por controlar a síntese de lipídios e carboidratos e manter a integridade da parede celular (JONES et al., 1981), também participa das reações de glicólise e dos processos de obtenção e transporte de energia (GUTIERREZ, 1994). Como polifosfato, pode servir como um carregador para o transporte ativo da glicose (STEVNINK \& ROTHSTEIN, 1965).

De acordo com SUOMALAINEN \& OURA (1970), o fósforo é absorvido pela célula na forma de ânion $\mathrm{H}_{2} \mathrm{PO}_{4}^{-}$, o qual predomina em meio de $\mathrm{pH} 4,0$.

STUPIELLO \& HORII (1981) recomendaram teores de fóforo nos níveis de 125 a 150 ppm de $\mathrm{P}_{2} \mathrm{O}_{5}$, para que ocorra uma fermentação alcóolica de bom 
rendimento, enquanto que para MAIORELLA et al (1981) o teor de fósforo necessário para meio sintético foi de $350 \mathrm{ppm}$. JONES et al. (1981) recomendaram 18,6 mg de fósforo para a síntese de $1 \mathrm{~g}$ de células para ótimas taxas de fermentações.

Mostos, principalmente de caldo de cana-de-açúcar e mistos, têm apresentado teores variáveis de $\mathrm{P}_{2} \mathrm{O}_{5}$, via de regra, superiores ao necessário, que pode ser observado inclusive pelos conteúdos que surgem na vinhaça e que têm variado de 20 a $90 \mathrm{ppm}$ de $\mathrm{P}_{2} \mathrm{O}_{5}$ (STUPIELLO \& HORII, 1981). Os teores de fósforo verificados nos mostos de destilarias anexas e autônomas situaram-se entre 30 e 184 ppm (AMORIM, 1985).

\subsubsection{Potássio}

O metabolismo da glucose e frutose é grandemente estimulado por potássio, em meio ácido, sendo que cálcio, magnésio e sódio, apresentam efeitos menores (ROTHSTEIN \& DEMIS, 1953).

São várias as funções que o potássio tem na levedura. Entre elas encontram-se, atuação como ativador em uma série de reações de glicólise e em outros passos do metabolismo (AMORIM, 1977).

O potássio quando no meio fermentativo, estimula a fermentação alcóolica (VISURI \& KIRSOP, 1970; REED \& PEPPLER, 1973) e muda o pH ótimo para valores mais baixos (VISURI \& KIRSOP, 1970). 
RODELLA \& FERRARI (1977), estudando os efeitos da fertilização da cana-de-açúcar sobre sua qualidade como matéria prima, encontraram teores de $\mathrm{K}_{2} \mathrm{O}$ no caldo, expressos em porcentagem, variando de 2,58 a 4,31\%. Enquanto CÉSAR et al. (1978), pesquisando os níveis deste elemento nas variedades IAC 52/134, NA 56-79 e CB 41-76, encontraram valores oscilando entre 120,50 e $433,80 \mathrm{mg}$ de $\mathrm{K}_{2} \mathrm{O}$ por 100 ml de caldo.

Células multiplicadas em meios contendo $3.500 \mathrm{ppm}$ de potássio, têm a piruvato descarboxilase mais ativa (BARTLEY \& BROOMHEAD, 1971), enquanto que JONES (1986) recomendou concentrações ótimas de potássio entre 78 a 390 ppm. AMORIM (1985) relatou que nos mostos utilizados nas destilarias autônomas e anexas, os teores de potássio variaram de 700 até 4.000 ppm, não sendo necessário, portanto, a suplementação com este elemento.

\subsubsection{Magnésio e cálcio}

O magnésio foi identificado como um elemento importante na restauração da atividade fermentativa das leveduras reduzida pela presença de etanol (DOMBEK \& INGRAM, 1986). Também, a adição de concentrações entre 30 e 80 ppm de cálcio provocou aumento da tolerância ao etanol nas leveduras Saccharomyces cerevisiae, $S$. bayanus e Kluyveromyces marxianus (NABAIS et al., 1988). 
JONES et al (1981) recomendaram teores de 120ppm para magnésio e 60 ppm para cálcio, enquanto que MAIORELLA et al. (1981) citaram 53 ppm para magnésio e 35 ppm para cálcio para estimular o crescimento da levedura.

SALTUKOGLU \& SLAUGTHER (1983) relataram que o cálcio retardou o crescimento da levedura quando presente em quantidade 10 vezes maior do que magnésio.

Os conteúdos de cálcio e magnésio apresentados por mostos de destilarias anexas e autônomas encontraram-se em cerca de 130 até $900 \mathrm{ppm}$ de magnésio e de 40 até 1.000 ppm de cálcio (AMORIM, 1985).

\subsubsection{Micronutrientes}

Os micronutrientes são elementos essenciais para o crescimento das leveduras e para o processo fermentativo, sendo necessários em quantidades que variam desde 0,1 a $100 \mu \mathrm{mol}$ (JONES et al., 1981). São micronutrientes o zinco, cobre, ferro, iodo, boro, cobalto e alumínio (GUTIERREZ, 1994).

De acordo com SCRUTTON et al. (1970), o zinco é um elemento essencial na nutrição da levedura, pois faz parte do grupo prostético de algumas enzimas da levedura como a piruvato carboxilase e segundo FORBES (1967) da desidrogenase alcóolica. O zinco ativa outras enzimas como a enolase e aldolase (FORBES, 1967). Atua sobre o crescimento das leveduras, fazendo parte das RNA polimerases (AULD et al., 1976; WANDZILAK \& BENSON, 1977). 
Na deficiência de zinco, ocorre uma tendência para aumento da produção de etanol resultante da menor formação de biomassa (Nordstrom ${ }^{1}$ citado por GUTIERREZ, 1994; GUTIERREZ, 1994) e menor produção de glicerol (Oura² citado por GUTIERREZ, 1994; GUTIERREZ, 1994). Porém, o tempo de fermentação é aumentado (GUTIERREZ, 1994).

MAIORELA et al. (1981) recomendaram para a obtenção de meio sintético, os elementos boro, cobalto, iodo e alumínio.

O elemento manganês é necessário para síntese de proteínas (JONES et al., 1981) e, o ferro e cobre fazem parte da estrutura dos citocromos (LEHNINGER, 1970).

\subsubsection{Vitaminas}

As vitaminas fazem parte do metabolismo das leveduras participando das coenzimas como NAD, NADP, PAD, Coenzima A, TPP, fosfato de piridoxal (LEHNINGER, 1970).

O teor de piruvato intracelular das leveduras reduz-se quando tiamina é adicionada ao meio de fermentação (TREVELYAN \& HARRISON, 1954). Já

1 NORDSTROM, K. Yeast growth and glycerol formation. Acta Chemica Scandinavica, Copenhagen, 20(4): 1016-25, 1966.

2 OURA, E. Reaction products of yeast fermentations. Process Biochemistry, London, 12: 19-35, 1977. 
SUOMALAINEN \& AXELSON (1956) verificaram que na fermentação de glucose, frutose e manose, a adição de tiamina ativou a liberação de gás carbônico.

A tiamina é necessária para a atividade de piruvato descarboxilase e o ácido pantotênico para a formação da Coenzima A, necessários para os processos de biossíntese (LEHNINGER, 1970).

As vitaminas biotina e ácido pantotênico são citadas por JONES et al. (1981), como sendo essencias para todas as leveduras, porém, existindo diferenças entre as leveduras quanto às demais vitaminas. MAIORELLA et al. (1981) recomendaram para o meio sintético, as vitaminas: biotina, ácido pantotênico, inositol, tiamina, piridoxina, ácido p-aminobenúsico e ácido nicotínico.

HENRY et al. (1977) verificaram que as leveduras deficientes em inositol apresentaram redução do potássio a nível de ATP ocorrendo a morte das células após 4 horas de deficiência. Foi relatado uma menor produção de etanol com as deficiências de ácido pantotênico e tiamina, fato que pode ser explicado pelo maior tempo de fermentação observado, resultando em maior quantidade de açúcares residuais (GUTIERREZ, 1994).

\subsubsection{Inibidores}

Durante o processo da fermentação alcóolica, ocorre produção de massa celular, glicerol, ácido succínico, ácido acético, ácido lático, álcoois superiores etc. que ocasionam uma menor eficiência da fermentação (GUTIERREZ, 1994). 
O álcool é o produto principal da glicólise em Saccharomyces cerevisiae e é conhecido por inibir a fermentação e causar outros efeitos desfavoráveis às células de leveduras, tais como: diminuição na taxa de crescimento e redução na viabilidade celular. Uma das justificativas dos efeitos adversos do etanol tem se concentrado na interação deste produto com os lipídios da membrana plasmática (PASCUAL et al., 1987).

Por muito tempo as atenções foram voltadas para o efeito inibidor do etanol sobre as leveduras. $O$ aparente efeito muito tóxico do etanol sobre as leveduras tem sido pesquisado empiricamente com base no fato de que outros metabólitos que não o etanol, são formados durante a fermentação e podem afetar o desempenho da levedura (LAFON-LAFOURCADE et al., 1984; VIEGAS et al., 1989).

Segundo AMIN et al. (1983), teoricamente a produção de etanol a partir de glicose é de $51,11 \%(\mathrm{p} / \mathrm{p})$. Porém, como muitos subprodutos são sintetizados simultaneamente, a nível de laboratório, a produção é baixa (HARRISON \& GRAHARAM, 1970; BEVERES \& VERACHTERT, 1976).

Em fermentações experimentais utilizando Saccharomyces cerevisiae e Kluyveromyces marxianus, VIEGAS et al. (1989) relataram a inibição do desenvolvimento dessas leveduras por ácidos octanóico e decanóico, subprodutos da fermentação etanólica em associação com o etanol, principal produto da fermentação. Verificaram ainda, que o efeito tóxico aumenta com o decréscimo do $\mathrm{pH}$ nos valores de 5,4 para 3,0 indicando que a forma não dissociada é a molécula tóxica. Para Saccharomyces bayanus, SÁ-CORREIA (1986) concluiu em seu trabalho que a 
presença desses ácidos graxos, atuam sinergicamente com o etanol resultando num decréscimo na taxa específica de seu desenvolvimento, mesmo em concentrações presentes no vinho e na cerveja. Já LAFON-LAFOURCADE \& RIBEREAU-GAYON (1984) verificaram que álcoois superiores, etil-ésteres e ácidos graxos têm sido identificados entre os produtos secundários do metabolismo de levedura que, em associação com o etanol, podem causar inibição global durante a fermentação alcóolica. Contudo, em relação ao ácido lático o etanol produzido não exerce influência em seu efeito inibidor (LETOURNEAU \& VILLA, 1987; NGANG et al., 1989).

CYZEWSKI \& WILKE (1977), através do estudo de fermentações com reciclo à vácuo, relataram a existência de materiais tóxicos inibindo o desenvolvimento da levedura sob uma condição de pequena sangria no fermentador. Sugeriram ainda, que muitas substâncias não voláteis acumulam-se no fermentador e inibem o desenvolvimento da levedura.

Segundo STUPIELLO (1984), substâncias tóxicas para as leveduras como os ácidos fórmico, acético e lático, sulfito, acetaldeído, ésteres, glicerol e outras, acumulam-se normalmente pela recirculação do vinho, através do fundo de dorna e do leite de leveduras e, da água de lavagem de gases extraídos das dornas fechadas.

MAIORELLA et al. (1983) realizaram em laboratório uma fermentação alcoólica a vácuo, para determinar a produção de subprodutos e os níveis de inibição em fermentação com Saccharomyces cerevisiae. Assim, determinaram para acetaldeído, glicerol, ácidos fórmico, lático e acético, 1-propanol, 2-metil-1-butanol e 2,3,-butanodiol, o efeito tóxico potencial para a levedura. 
Para EGUCHI (1989), os metabólitos como acetaldeído, glicerol, ácidos fórmico e lático, 1-propanol, butanol, butanodiol etc, atuam como inibidores da fermentação alcoólica, mas em concentrações muito superiores as encontradas nas dornas de fermentação. 


\section{MATERIAL E MÉTODOS}

O experimento foi desenvolvido durante a safra de $\cdot 1992 / 93$, nos laboratórios do Departamento de Ciência e Tecnologia Agroindustrial da Escola Superior de Agricultura "Luiz de Queiroz" da Universidade de São Paulo - Campus de Piracicaba.

\subsection{Material}

\subsubsection{Matéria-prima}

Como matéria-prima foram utilizados colmos de cana-de-açúcar sadios, não florescidas e florescidas, da variedade SP 70-1143, provenientes da lavoura da Usina Açucareira Ester S.A., Cosmópolis - SP. A cana-de-açúcar utilizada não foi queimada, sendo cortada manualmente e transportada imediatamente para o laboratório.

A variedade SP 70-1143, de considerável importância agrícola, de acordo com NUNES JR et al.(1982) e o artigo NOVAS variedades ...(1983), é conhecida por sua característica de adaptar-se a diferentes tipos de solo. Em relação à exigência de fertilidade natural dos solos, ela é a menos exigente, pois quando plantada em solos classificados como Areias Quartzozas, extremamente arenosos, tem se 
sobressaído entre as demais variedades comerciais (SEMINÁRIO..., 1982), apresentando extraordinário desempenho que proporciona elevada produtividade.

A variedade SP 70-1143 floresce nas mais diversas condições (SEMINÁRIO..., 1982), sendo propensa ao florescimento nas condições de cultivo das regióes canavieiras do Estado de São Paulo (NUNES JR et al., 1982). Além destas características, apresenta a de chochamento, principal consequência negativa do florescimento.

\subsubsection{Mosto}

Foi obtido a partir do caldo extraído de colmos de cana-de-açúcar da variedade SP 70-1143 não florescida e florescida, e dilurdo até aproximadamente $18^{\circ}$ Brix. Para cada ciclo dos ensaios fermentativos foi feito extração do caldo de 10 colmos da mesma amostra.

\subsubsection{Microrganismo}

Foi utilizado o fermento comercial (tipo prensado). 


\subsubsection{Fermentadores}

Os dois fermentadores utilizados, foram projetados e construídos no Departamento de Ciência e Tecnologia Agroindustrial, ESALQ-USP . Cada um era constituído de cuba de vidro de volume total de 3,5 litros ( volume útil 2,5 litros), dotado de saída para retirada de amostras e de entradas para termômetro e o mosto. Em cada fermentador foi adaptado um agitador eletromagnético para manter o meio homogêneo, um banho termostatizado para manutenção da temperatura no fermentador (através de serpentina interna no fermentador).

\subsubsection{Centrífuga}

Para recuperação do fermento foi utilizada a centrífuga modelo PR-2 a 900.g, dotada de sistema de refrigeração $\left(0^{\circ} \mathrm{C}\right)$, com capacidade de trabalho igual a $750 \mathrm{ml}$ por recipiente, utilizando um tempo de centrifugação de 15 minutos. 


\subsection{Métodos}

\subsubsection{Açúcares Redutores Totais (ART) do mosto e Açúcares Redutores} Residuais Totais (ARRT) do vinho.

A determinação de açúcares redutores totais (ART) do mosto foi realizada pelo método volumétrico de LANE \& EYNON (1923), com prévia inversão ácida da sacarose. Sendo os açúcares redutores residuais totais (ARRT) do vinho determinados pelo método de LANE \& EYNON (1923) modificado por ANDRIETTA \& CARUSO (1992).

\subsubsection{Volume de células de levedura}

Foi determinado a partir da centrifugação do vinho levurado pelo método de TRÍBOLI (1987)

\subsubsection{Brix e Pol do caldo extraído}

As determinações foram feitas segundo o método ICUMSA (1979). 
3.2.4. Brix, Pol e Fibra da cana

Determinações pelo método de TANIMOTO (1964).

3.2.5. Teor alcoólico do fermento e vinho

Foram determinados através do densímentro digital Anton-Paar modelo DMA-45 acoplado a banho termostatizado, com prévia separação do álcool em microdestilador Tecnal modelo TE - 012, segundo AMORIM et al. (1982).

3.2.6. Acidez total do mosto e acidez volátil do mosto e do vinho

As análises foram realizadas, segundo AMERINE \& OUGH (1974).

3.2.7. Nitrogênio total do mosto

Foi determinado, segundo VILLELA et al. (1972).

3.2.8. Fósforo inorgânico do mosto

Foi utilizado o método colorimétrico, segundo GOMORI (1942). 
3.2.9. Potássio do mosto

Foi utilizada a fotometria de chama, de acordo com o método de GLÓRIA \& RODELLA (1972).

\subsubsection{Viabilidade e Brotamento celulares}

Foram analisados por microscopia em câmara de Neubauer (PIERCE, 1970).

\subsubsection{Eficiência Fermentativa}

Foi determinada mediante cálculo estequiométrico através da seguinte expressão simplificada:

$$
\mathrm{Ef}=\frac{\left({ }^{\circ} \mathrm{Gl}_{\mathrm{v}} \times \mathrm{V}_{\mathrm{v}}-{ }^{\circ} \mathrm{Gl}_{\mathrm{f}} \times \mathrm{V}_{\mathrm{f}}\right)}{\mathrm{ART}} \times 88,26 \text { Sendo, }
$$

Ef - Eficiência Fermentativa

${ }^{\circ} \mathrm{Gl}_{\mathrm{v}}$ - Grau alcóolico do vinho (fermentador)

${ }^{\circ} \mathrm{Gl}_{\mathrm{f}}$ - Grau alcóolico do fermento

$V_{v}$ - Volume do vinho levurado $=2.500 \mathrm{ml}$

$V_{f}$ - Volume do fermento $=750 \mathrm{ml}$

ART - Açúcares Redutores Totais do mosto (g/litro) 
Tal procedimento foi adotado para os ensaios fermentativos com mostos de caldo de colmos de canas não florescidas e florescidas.

3.3. Condições operacionais

Temperatura

Volume de Fermento

pH do Fermento

Brix do mosto

ART do Mosto

Agitação.

Teor Alcólico
$33 \pm 1^{\circ} \mathrm{C}$

$750 \mathrm{ml}$ (30\% do vol. total)

aproximadamente 2,5

aproximadamente $18^{\circ}$

$170-190 \mathrm{~g} / 1$

$60 \mathrm{rpm}$

$6,00-9,00$

\subsection{Procedimento experimental}

Os colmos de cana separados em dois feixes contendo aproximadamente 40 colmos de cana não florescida e de cana florescida cada, foram despalhados e normalmente despontados no laboratório.

Os passos dos ítens a seguir são compilados na Figura 1. 
Cana-de-açúcar

var. SP 70-1143

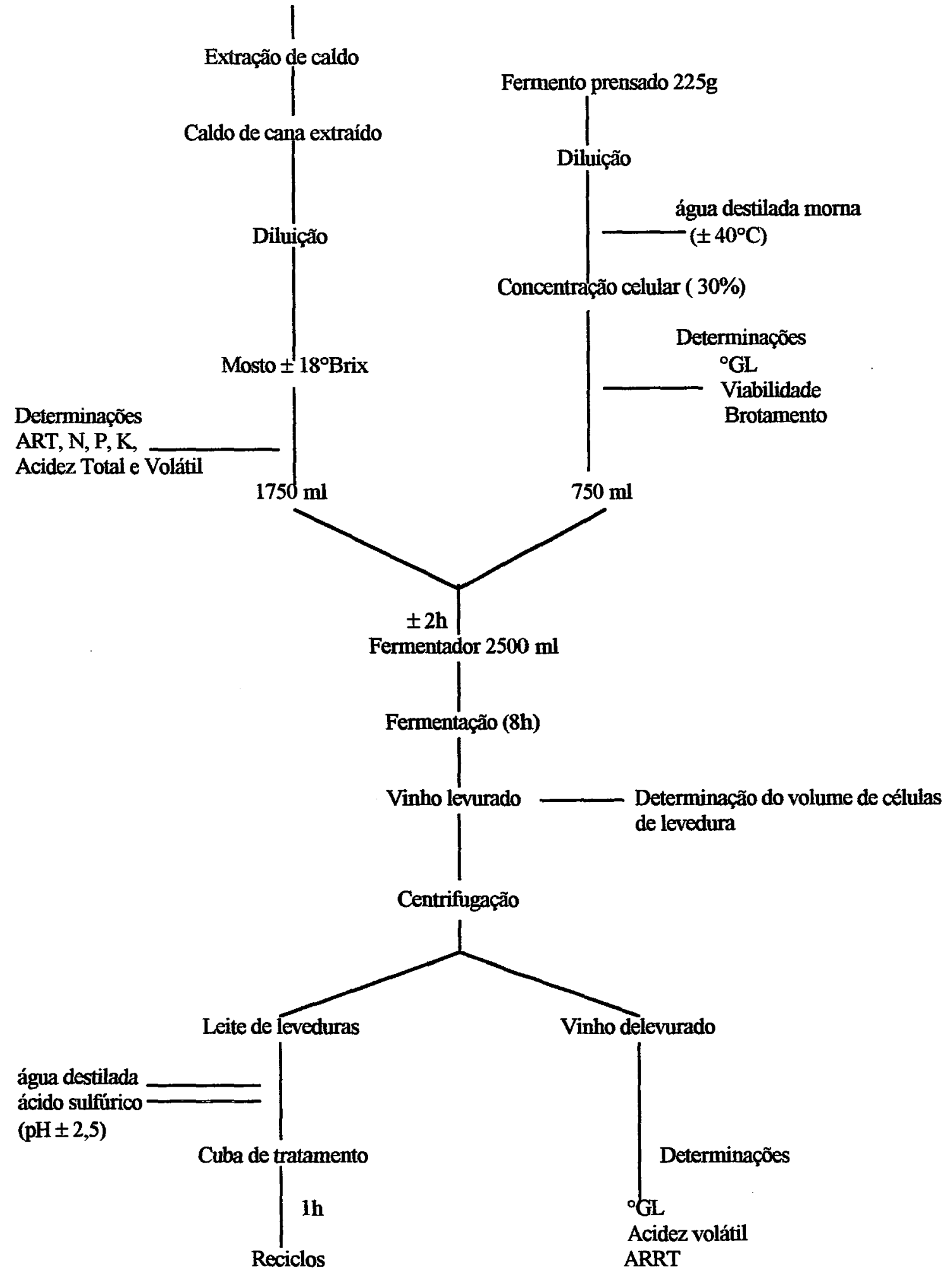

Figura 1. Fluxograma experimental 


\subsubsection{Preparo do mosto}

O caldo de colmos de cana, para cada ensaio, foi obtido da desintegração e extração do caldo de 10 colmos tomados ao acaso da amostra e diluído a aproximadamente $18^{\circ}$ Brix para constituir o mosto.

O volume do mosto utilizado para cada ciclo fermentativo foi de 1750 mililitros.

Não foi feita suplementação de nutrientes no mosto.

Foram feitas as seguintes determinações no mosto: Brix, Pol, ART, $\mathrm{N}, \mathrm{P}, \mathrm{K}$, acidez total e volátil.

\subsubsection{Preparo do Fermento}

Foi estabelecido o uso de inóculo correspondente a $30 \%$ do volume útil do fermentador, sendo este o procedimento geralmente utilizado pelas destilarias.

Foram pesados 225 gramas de fermento prensado e adicionado água destilada morna $\left( \pm 40^{\circ} \mathrm{C}\right.$ ) até o volume de 750 mililitros. $\mathrm{O}$ pH foi ajustado com adição de ácido sulfúrico concentrado p.a., a 2,5. Após 1 hora de tratamento ácido, o fermento era utilizado na fermentação.

No fermento foram feitas análise de viabilidade e brotamento celulares. Também foi determinado o teor alcoólico a fim de permitir o cálculo da eficiência fermentativa. Isso para cada ensaio e seus respectivos ciclos. 
No vinho delevurado foram feitas as determinações de açúcares redutores residuais totais, teor alcoólico e acidez volátil.

\subsubsection{Ensaios Fermentativos}

Os fermentadores foram alimentados simultaneamente com fermento $(750 \mathrm{ml})$ e mosto $(1750 \mathrm{ml})$, totalizando um volume de 2.500 mililitros. A alimentação foi por batelada alimentada, em um período de aproximadamente 2 horas.

A fermentação foi conduzida sob agitação para homogeneização nos fermentadores, os quais eram providos de sistema de controle de temperatura $(33 \pm$ $\left.1^{\circ} \mathrm{C}\right)$.

Foi realizado um total de 4 ensaios com 4 ciclos completos ( 1 ciclo + 3 reciclos) cada, sendo um fermentador alimentado com mosto de caldo de cana não florescida e outro de florescida.

O tempo de fermentação estabelecido foi de 8 horas. A espuma do meio fermentativo foi controlada com adição de gotas de anti-espumante.

\subsubsection{Recuperação do Fermento}

Após oito horas de fermentação o fermento de cada fermentador era recuperado por centrifugação em centrífuga refrigerada à 900 .g por 15 minutos. O leite de leveduras (20\% do fermento) obtido era diluído com água destilada até completar 750 
ml. Em seguida era ajustado o pH com ácido sulfúrico p.a. até 2,5 e deixado em agitação por 1 hora. 


\section{RESULTADOS E DISCUSSÃO}

\subsection{Parâmetros de Qualidade dos Colmos e Caldos Extraídos}

A composição tecnológica da matéria-prima e do caldo extraído encontram-se na Tabela 1.

\subsection{Açúcares Redutores Totais do Mosto}

Os resultados de açúcares redutores totais obtidos para o mosto do caldo de colmos de cana-de-açúcar não florescida e florescida, bem como as médias para os 4 ensaios, são apresentados na Tabela 2. 


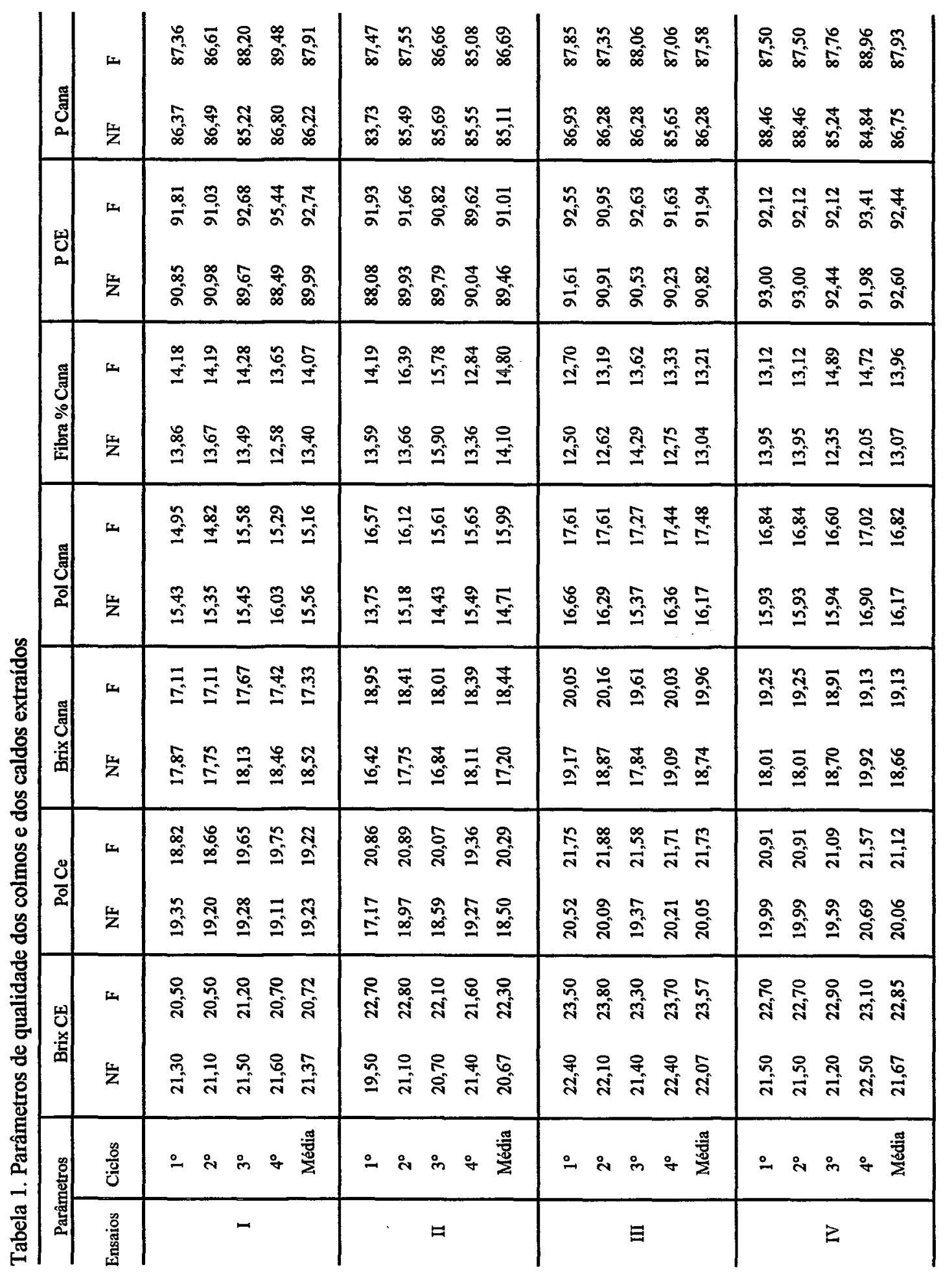


Tabela 2. Resultados obtidos das determinações de ART expressos em g de açúcar invertido/litro de mosto.

\begin{tabular}{|c|c|c|c|c|c|c|c|c|}
\hline \multirow{3}{*}{ Ciclos } & \multicolumn{8}{|c|}{ ENSAIOS } \\
\hline & \multicolumn{2}{|r|}{ I } & \multicolumn{2}{|c|}{ II } & \multicolumn{2}{|c|}{ III } & \multicolumn{2}{|c|}{ IV } \\
\hline & NF & F & NF & F & NF & F & NF & F \\
\hline $1^{\circ}$ & 180,77 & 180,03 & 180,27 & 179,97 & 171,09 & 173,92 & 184,45 & 181,91 \\
\hline $2^{\circ}$ & 180,53 & 183,40 & 175,52 & 178,35 & 175,09 & 170,39 & 184,38 & 181,49 \\
\hline $3^{\circ}$ & 181,03 & 179,82 & 176,06 & 174,61 & 175,31 & 174,62 & 188,27 & 188,04 \\
\hline $4^{\circ}$ & 181,80 & 180,98 & 172,53 & 171,09 & 169,63 & 175,31 & 177,24 & 178,87 \\
\hline Média & 181,03 & 181,05 & 176,09 & 176,01 & 172,78 & 173,56 & 183,58 & 182,58 \\
\hline
\end{tabular}

Os dados mostram valores de ART, expressos em $\mathrm{g}$ de açúcar invertido por litro de mosto, variando de 169,63 a 188,27 para as canas não florescidas e de 170,39 a $188,04 \mathrm{~g}$ de açúcar invertido por litro de mosto para as canas florescidas. Como pode-se observar, os mostos provenientes das canas florescidas apresentaram, em média, valores da mesma ordem daqueles provenientes do caldo de canas não florescidas (Figura 2), diferindo assim dos dados apresentados por MIOCQUE (1965) e ALEXANDER (1991). Estes autores relataram que para o desenvolvimento dos orgãos reprodutores e para haver fecundação, as necessidades de substâncias nutritivas são consideráveis, o que provoca o esgotamento de reservas celulares, determinando diminuição no teor de sacarose e consequentemente do ART, considerando-se que a sacarose participa com mais de $95 \%$ do ART. 


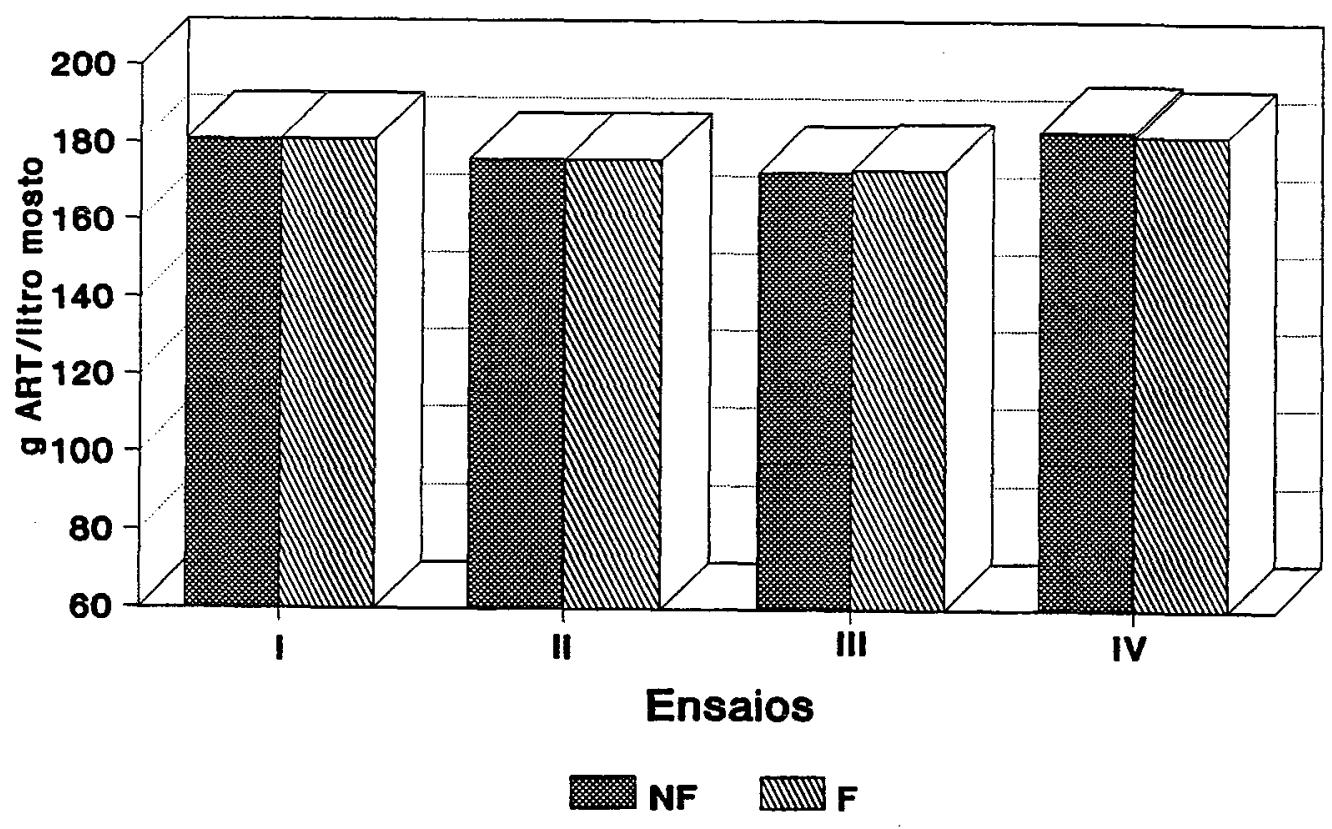

Figura 2. Médias de ART no mosto de caldo de colmos de cana-de-açúcar não florescidas e florescidas nos diferentes ensaios.

Tal observação, por analogia, também não está em concordância com BARBIERI et al. (1984), segundo os quais a cana ao florescer praticamente perde as folhas sintetizadoras não aumentando assim o teor de sacarose, ao contrario, o sintetizado tenderá a ser utilizado para a formação e emissão da panícula. Quando se observa os valores médios para brix e pol do caldo extraído, nota-se que de forma geral, tais valores foram superiores para o caldo de cana florescidas, o mesmo ocorrendo com os valores médios de pureza do caldo extraído conforme demonstrado na Tabela 1. Essas verificações também reforçam a discordância dos valores de ART encontrados, com as citações de STEHLE (1955), MIOCQUE (1965), BARBIERI et al. (1984) e ALEXANDER (1991). 
As variações nos valores de ART obtidos, dentro da própria amostra colhida para cada ensaio, poderia ser justificado pelo fato que para preparo do mosto foram tomados 40 colmos seguidos no sulco, de um mesmo talhão, sendo que existe variação no teor dos elementos de um colmo para outro. $O$ que por analogia vem de encontro ao relatado por ALMEIDA et al. (1945), HERNANDEZ (1965), FOGLIATA \& MORIN (1975), BARBIERI et al. (1984), IAIA et al. (1985) e BARBIERI \& LOPES (1987).

Embora os resultados não tenham se apresentado de forma regular, como já citado houve variação dentro da própria amostra, estes não influenciaram a eficiência fermentativa (Tabela 10).

\subsection{Acidez Total e Volátil do Mosto}

Os resultados de acidez total e volátil do mosto de caldo de colmos de canas não florescidas e florescidas, bem como as médias para os 4 ensaios, são apresentados na Tabela 3. 


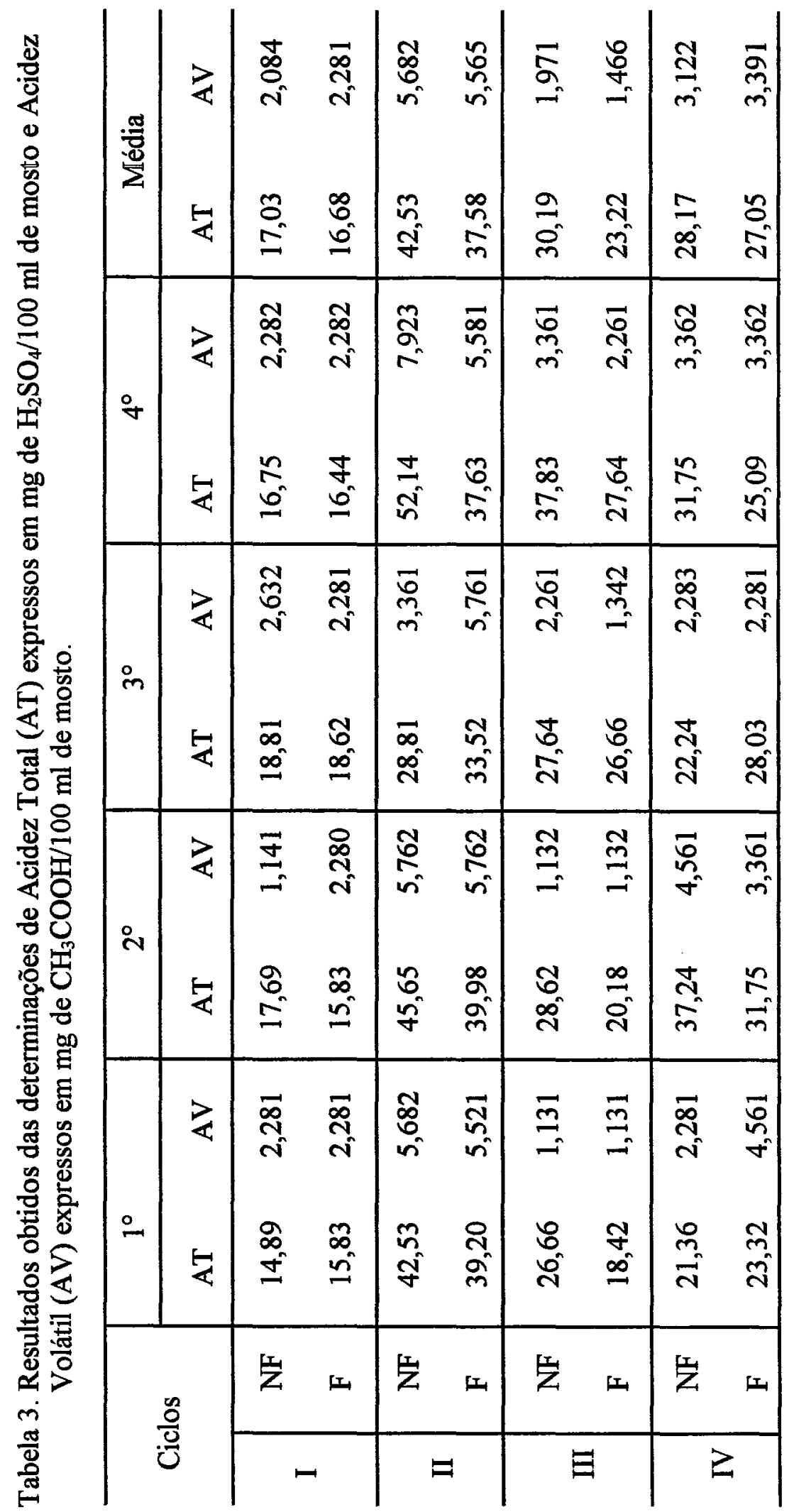


Os dados de acidez total expressos em $\mathrm{mg}$ de $\mathrm{H}_{2} \mathrm{SO}_{4}$ por $100 \mathrm{ml}$ de mosto, apresentam valores que variam de 14 a 52 para o mosto do caldo de cana não florescida e de 15 a 40 para a cana florescida. Para acidez volátil os valores variam de 1 a 8 para canas não florescidas e de 1 a $6 \mathrm{mg}$ de $\mathrm{CH}_{3} \mathrm{COOH}$ por $100 \mathrm{ml}$ de mosto para a florescida, que demonstram canas com o mesmo estádio de deterioração.

Pode-se observar que os dados para acidez total e volátil tanto para canas não florescidas como para florescidas não tiveram uma tendência regular, o que poderia ser explicado pelo fato que as canas apresentaram diferentes graus de maturação, sendo provavelmente as menos maduras as com maior acidez. Contudo, verificando-se as médias obtidas para os quatro ensaios, nota-se que os mostos de caldo de canas não florescidas apresentaram maiores valores de acidez total, o que poderia ser devido às canas florescidas estarem completamente maduras, conforme 0 artigo 0 FLORESCIMENTO.... (1951). Consequentemente, tal fato vem de encontro ao relatado por ALMEIDA et al. (1945), HERNANDEZ (1965), FOGLIATA \& MORIN (1975), BARBIERI et al. (1984), IAIA et al. (1985) e BARBIERI \& LOPES (1987).

Quanto às médias da acidez volátil no mosto para os quatro ensaios, nota-se que praticamente houve uma similaridade entre os resultados.

Partindo-se das verificações acima poderia ser constatado que o processo de florescimento não causou deterioração do caldo e que os conteúdos de acidez total e volátil presentes no mosto não foram inibitórios para o processo fermentativo considerando os valores de viabilidade celular (Tabela 4) e da eficiência de fermentação (Tabela 10). 


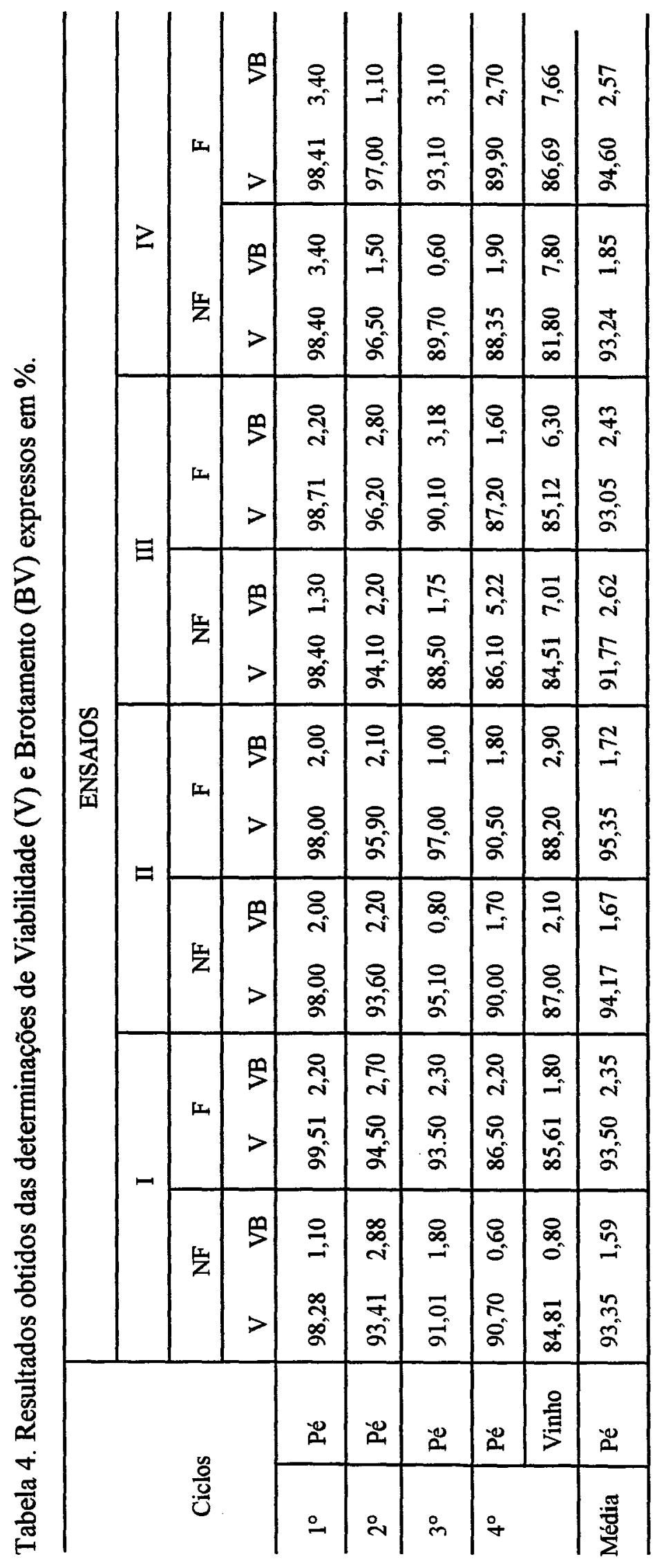




\subsection{Nitrogênio}

Os valores das concentrações de nitrogênio total no mosto de caldo de colmos de cana-de-açúcar não florescida e florescida, bem como as médias para os 4 ensaios são apresentados na Tabela 5.

Tabela 5. Resultados obtidos das determinações de Nitrogênio Total expressos em mg de N/litro de mosto.

\begin{tabular}{|c|c|c|c|c|c|c|c|c|}
\hline \multirow{3}{*}{ Ciclos } & \multicolumn{8}{|c|}{ ENSAIOS } \\
\hline & \multicolumn{2}{|c|}{ I } & \multicolumn{2}{|c|}{ II } & \multicolumn{2}{|c|}{ III } & \multicolumn{2}{|c|}{ IV } \\
\hline & NF & $\mathbf{F}$ & NF & $\mathbf{F}$ & NF & $\mathbf{F}$ & NF & $\mathbf{F}$ \\
\hline $1^{\circ}$ & 242 & 228 & 650 & 242 & 470 & 450 & 456 & 265 \\
\hline $2^{\circ}$ & 241 & 171 & 643 & 171 & 414 & 371 & 435 & 265 \\
\hline $3^{\circ}$ & 270 & 267 & 642 & 314 & 443 & 364 & 449 & 293 \\
\hline $4^{\circ}$ & 328 & 299 & 686 & 251 & 414 & 407 & 407 & 286 \\
\hline Média & 270 & 241 & 655 & 244 & 435 & 398 & 437 & 277 \\
\hline
\end{tabular}

Os resultados variaram de 241 a $686 \mathrm{mg}$ de $\mathrm{N}$ por litro de mosto,no caso de canas não florescidas e de 171 a $450 \mathrm{mg}$ de $\mathrm{N}$ por litro de mosto para as florescidas. Verifica-se que os mostos do caldo de canas florescidas sempre 
apresentaram, na média, valores menores em relação aos das não-florescidas (Figura 3). Pelas médias obtidas dos quatro ensaios pode-se observar que o mosto de caldo de canas florescidas apresentaram um teor de nitrogênio aproximadamente $35 \%$ menor em relação ao de canas não florescidas. O que poderia ser explicado pelo fato que a cana para 0 processo de indução floral e emergência da panícula, faz uso de tal nutriente, o que está de acordo com MIOCQUE (1965) e ALEXANDER (1991). Mas de acordo com o relato de HUMBERT (1963) o nitrogênio frequentemente poderia estar sendo liberado pelo sistema de raizes durante o florescimento. Ocorrendo, neste período, também uma redução na absorção pelas raizes, o que acentua a queda nos teores desse elemento.

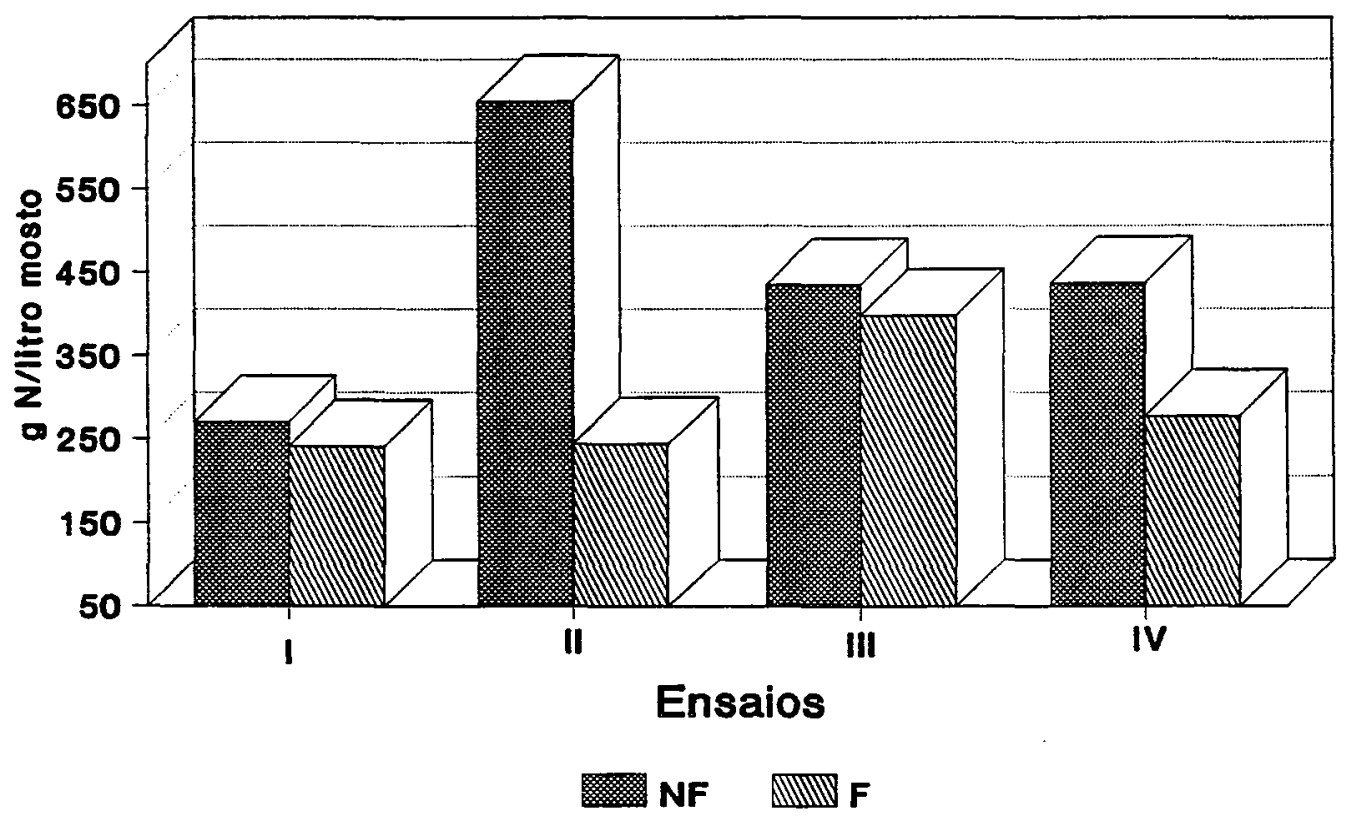

Figura 3. Médias de Nitrogênio Total no mosto de caldo de colmos de cana-de-açúcar não florescidas e florescidas nos diferentes ensaios. 
Pode-se observar pelos dados apresentados que houve uma variação nos teores de nitrogênio dentro da própria amostra, fato que poderia ser devido às diferenças entre o teor de um colmo e outro, já que estes foram colhidos, provavelmente de uma mesma touceira e portanto com diferentes idades e estádios de maturação.

Comparando-se com os valores encontrados na literatura, pode-se concluir que os obtidos são superiores aos citados por GEERLIGS (1924), WIGGINS (1969). Em relação aos valores máximos, tanto para canas não florescidas quanto para as florescidas, são superiores aos encontradas por MAHAMUNI et al.(1973) ,estando os valores mínimos, aquém neste caso.

O nitrogênio é um elemento importante, pois ele entra como constituinte de várias substâncias orgânicas presentes na levedura (WHITE, 1954). E, segundo AMORIM (1977), é efetor positivo das enzimas fosfofrutoquinase e aldolase, acelerando a produção de piruvato e consequentemente de etanol em anaerobiose. Assim em meio deficiente em nitrogênio o tempo de fermentação tende a prolongar-se (HARRISON \& GRAHAM, 1970; AMORIM, 1977; STUPIELLO \& HORII, 1981).

Desse modo os, menores valores encontrados para o mosto do caldo de canas florescidas, poderiam ser problemáticos para o desempenho das fermentações. Contudo, tal diferença não foi limitante, não afetando assim a fermentação dentro do tempo estipulado (Tabela 10).

Somente os valores máximos encontraram-se em níveis satisfatórios, em relação ao preconizado por AMORIM (1977), muito embora isto parece não ter influenciado negativamente a fermentação, pois as eficiências fermentativas para o caso 
das canas florescidas não apresentaram desvantagem em relação às não florescidas, uma vez que em ambos os casos do primeiro ao quarto ciclo houve uma tendência de aumento dos valores, atingindo neste último, valores considerados ótimos.

Embora os mostos de caldo de canas florescidas tenham apresentado teores de nitrogênio menores em relação aos de não florescida, tais teores, provavelmente foram suficientes para utilização pela levedura em seu desenvolvimento, viabilidade e brotamento (Tabelas 6 e 4).

Tabela 6. Resultados obtidos das determinações do volume de células de levedura (\%) do vinho.

\begin{tabular}{c|cc|cc|cc|cc}
\hline \multirow{2}{*}{ Ciclos } & \multicolumn{7}{|c|}{ ENSAIOS } \\
\cline { 2 - 9 } & \multicolumn{2}{|c|}{ I } & \multicolumn{2}{|c|}{ II } & \multicolumn{2}{|c}{ III } & \multicolumn{2}{|c}{ IV } \\
\cline { 2 - 9 } & NF & F & NF & F & NF & F & NF & F \\
\hline $1^{\circ}$ & 11,00 & 11,00 & 12,00 & 11,50 & 11,00 & 11,00 & 11,00 & 11,00 \\
$2^{\circ}$ & 12,00 & 12,00 & 13,50 & 14,00 & 12,00 & 13,00 & 12,00 & 12,00 \\
$3^{\circ}$ & 11,00 & 11,00 & 14,00 & 14,50 & 11,50 & 11,50 & 11,00 & 11,00 \\
$4^{\circ}$ & 11,50 & 11,00 & 15,00 & 14,50 & 12,00 & 11,50 & 11,00 & 11,00 \\
\hline Média & 11,37 & 11,25 & 13,62 & 13,62 & 11,62 & 11,75 & 11,25 & 11,25 \\
\hline
\end{tabular}




\subsection{Fósforo}

Na Tabela 7, são apresentados os resultados dos teores de fósforo inorgânico no mosto de caldo de colmos de cana-de-açúcar não florescida e florescida, bem como as médias para os 4 ensaios.

Tabela 7. Resultados obtidos das determinações de Fósforo Inorgânico expressos em mg de $\mathrm{P}_{2} \mathrm{O}_{5} /$ litro de mosto.

\begin{tabular}{c|cc|cc|cc|cc}
\hline \multirow{2}{*}{ Ciclos } & \multicolumn{7}{|c|}{} & \multicolumn{2}{|c|}{ I } & \multicolumn{2}{c|}{ II } & \multicolumn{2}{|c|}{ III } & \multicolumn{2}{|c}{ IV } \\
\cline { 2 - 10 } & NF & F & NF & F & NF & F & NF & F \\
\hline $1^{\circ}$ & 132 & 184 & 150 & 115 & 100 & 87 & 131 & 100 \\
$2^{\circ}$ & 230 & 179 & 158 & 115 & 104 & 89 & 128 & 105 \\
$3^{\circ}$ & 108 & 79 & 96 & 121 & 105 & 96 & 122 & 111 \\
$4^{\circ}$ & 127 & 99 & 116 & 130 & 117 & 99 & 189 & 111 \\
\hline Média & 149 & 135 & 130 & 120 & 106 & 93 & 142 & 107 \\
\hline
\end{tabular}


Os dados apresentaram valores que variam de 96 a $230 \mathrm{mg}$ de $\mathrm{P}_{2} \mathrm{O}_{5} /$ litro de mosto de caldo de canas não florescidas e de 79 a $184 \mathrm{mg}$ de $\mathrm{P}_{2} \mathrm{O}_{5} /$ litro de mosto no caso das florescidas. As referidas faixas de variação, em comparação com os dados da literatura tiveram seus menores valores inferiores aos menores valores citados por STUPIELLO \& HORII (1981). Isto não acontece quando se considera o valor verificado por AMORIM (1985). Os extremos superiores das faixas obtidas foram superiores aos valores encontrados por STUPIELLO \& HORII (1981) e AMORIM (1985).

Pode-se observar que, de maneira geral, mostos provenientes de caldo de canas não florescidas apresentaram teores de fósforo superiores aos de canas florescidas, o que é verificado também pelos valores médios (Figura 4). Verificando-se as médias obtidas dos 4 ensaios, nota-se que o teor de fósforo apresentados para o mosto de caldo de canas florescidas é aproximadamente $15 \%$ menor quando comparados ao de canas não florescidas, o que do mesmo modo que o nitrogênio, poderia ser devido a utilização do elemento pela planta no processo de florescimento (MIOCQUE, 1965; ALEXANDER, 1991). A isto se acrescenta o fato que no período de florescimento a planta tem a absorção pelas raízes reduzida; citado por HUMBERT (1963). 


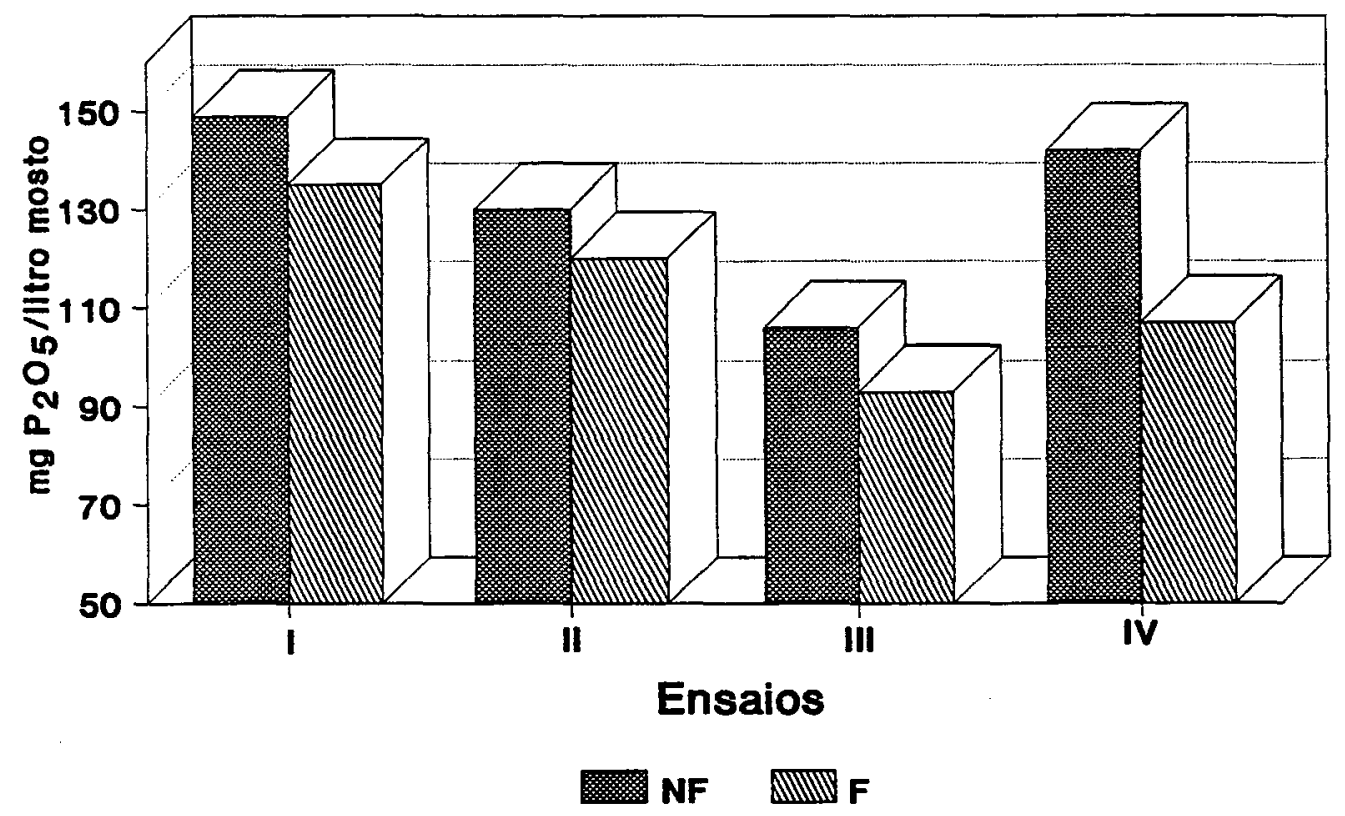

Figura 4. Médias de Fósforo Inorgânico no mosto de caldo de colmos de cana-de-açúcar não florescida e florescida nos diferentes ensaios.

Verifica-se que existiu diferença, dentro da mesma amostra, quanto ao teor de fósforo obtido, o que poderia ser explicado pela variação nos teores desse elemento existente entre um colmo e outro, os quais para o preparo do mosto, foram colhidos, provavelmente de uma mesma touceira e portanto com diferentes idades e estágios de maturação dos colmos.

O fósforo é essencial ao crescimento das leveduras e à fermentação (AMORIM, 1977; ZAGO, 1982). Ele é importante por controlar a síntese de lipídios e carboidratos e manter a integridade da parede celular (JONES et al., 1981). E, como 
é relatado por AMORIM (1977), também é importante na transformação do açúcar em álcool, assim como na produção de ATP, tanto na glicólise como na cadeia respiratória. O fósforo serve como carregador para o transporte ativo da glicose (STEVNINCK \& ROTHSTEIN, 1965).

Sendo o fósforo um elemento de máxima importância para o desempenho da fermentação, os menores teores do elemento apresentados, de maneira geral, nos mostos de canas florescidas, poderiam ser um fator para comprometer as fermentações, contudo esses teores não foram limitantes, não sendo possível observar esse efeito nas mesmas. Os valores de eficiência fermentativa para os quatro ensaios, no caso das canas não florescidas e florescidas, tiveram uma tendência a aumentar acabando por atingir valores considerados ótimos, no quarto ciclo (Tabela 10). Comparando-se as médias das eficiência fermentativas entre canas não florescidas e florescidas, verifica-se que as florescidas ora mostraram valores maiores, ora menores (Figura 6). Mesmos os mostos de caldo de canas florescidas tendo apresentado teores de fósforo inferiores aos de canas não florescidas, provavelmente, tais teores foram suficientes para uso pelas leveduras em seu desenvolvimento e manutenção (Tabelas 6 e 4). 


\subsection{Potássio}

Os resultados dos teores de potássio no mosto de caldo de colmos de cana-de-açúcar não florescida e de florescida, bem como as médias para os 4 ensaios são apresentados na Tabela 8.

Tabeia 8. Resultados obtidos das determinações de Potássio expressos em mg de $\mathrm{K}_{2} \mathrm{O}$ /litro de mosto.

\begin{tabular}{|c|c|c|c|c|c|c|c|c|}
\hline \multirow{3}{*}{ Ciclos } & \multicolumn{8}{|c|}{ ENSAIOS } \\
\hline & \multicolumn{2}{|r|}{ I } & \multicolumn{2}{|c|}{ II } & \multicolumn{2}{|c|}{ III } & \multicolumn{2}{|c|}{ IV } \\
\hline & NF & F & NF & $\mathbf{F}$ & NF & $\mathbf{F}$ & NF & F \\
\hline $1^{\circ}$ & 1832 & 1427 & 2285 & 1407 & 1880 & 1427 & 1446 & 1326 \\
\hline $2^{\circ}$ & 1458 & 949 & 1808 & 1388 & 2306 & 969 & 1407 & 1313 \\
\hline $3^{\circ}$ & 1427 & 1388 & 1880 & 962 & 1350 & 1398 & 1465 & 962 \\
\hline $4^{\circ}$ & 1407 & 612 & 1832 & 1330 & 1856 & 1311 & 1350 & 617 \\
\hline Média & 1531 & 1094 & 1951 & 1272 & 1848 & 1276 & 1417 & 1054 \\
\hline
\end{tabular}

Os resultados encontrados variaram de 1350 a $2285 \mathrm{mg}$ de $\mathrm{K}_{2} \mathrm{O}$ por litro de mosto para as canas não florescidas e de 612 a $1427 \mathrm{mg}$ de $\mathrm{K}_{2} \mathrm{O}$ por litro de mosto para as florescidas. Comparando-se com as citações encontradas na literatura, observa-se que os valores obtidos estão inseridos na faixa recomendada por JONES (1986) como adequada à fermentação. Os teores de potássio encontrados no mosto no 
caso de canas florescidas estão abaixo dos encontrados por RODELLA \& FERRARI (1977), sendo que somente o menor valor não se encontra inclú́do nas faixas de variação encontradas por CÉSAR et al. (1978) e AMORIM (1985). Em relação aos valores encontrados para mostos de caldo de canas não florescidas, o menor valor é inferior somente aos valores encontrados por RODELLA \& FERRARI (1978).

Verifica-se que os teores de potássio nos mostos para o caso de canas florescidas, sempre foram menores em relação aos de canas não florescidas, o que também pode ser verificado pelos valores médios (Figura 5). Comparando-se as médias dos quatro ensaios,pode-se observar que o mosto de caldo de canas florescidas mostrou ter aproximadamente $30 \%$ menos potássio que o de canas não florescidas, o que da mesma forma que foi para $\mathrm{N}$ e $\mathrm{P}$, poderia ser devido ao fato que a cana-de açúcar utilizou esse nutriente para o desenvolvimento dos orgãos reprodutores (MIOCQUE, 1965; ALEXANDER, 1991) e também, a cana na fase de florescimento, tem reduzida a absorção de nutrientes e água pelas raizes, sendo o potássio frequentemente excretado pelo sistema de raiz (HUMBERT, 1963). 


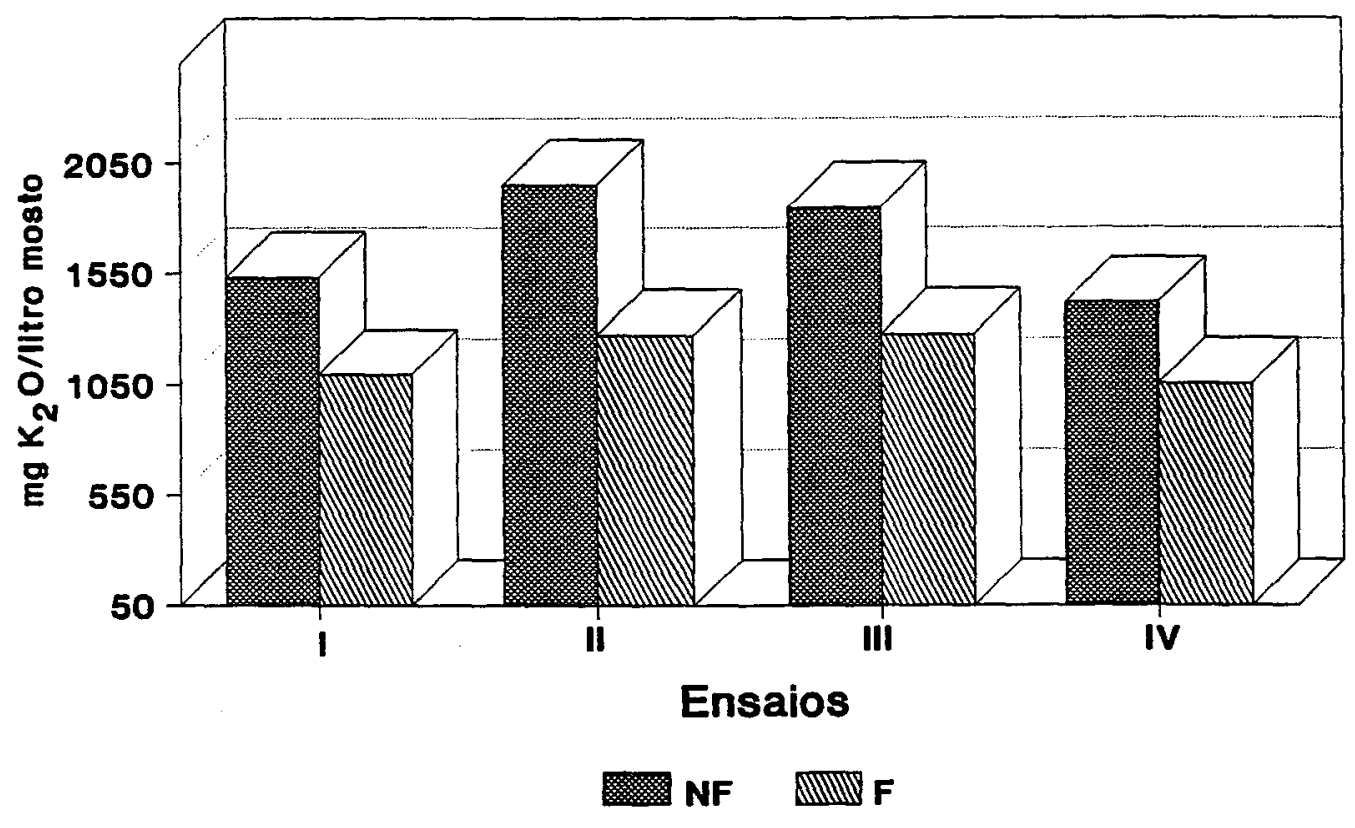

Figura 5. Médias de Potássio no mosto de caldo de colmos de cana-de-açúcar não florescida e florescida nos diferentes ensaios.

Ocorreram variações nos teores de potássio dentro do colmo de cana da mesma amostra, o que poderia ser atribuído ao fato que os colmos, foram colhidos, provavelmente de uma mesma touceira, apresentando assim diferentes idades e estádios de maturação,sendo que entre um colmo e outro existem diferenças nos teores dos elementos.

Pelas verificaçōes poderiam ser esperados problemas quanto ao desempenho da fermentação, já que o potássio atua na célula como ativador numa série de reações da glicólise e outros passos do metabolismo (AMORIM, 1977), sendo deste modo, muito importante nas fermentações estimulando-as (VISURI \& KIRSOP, 1970). 
Entretanto, não ocorreram problemas em relação ao desempenho fermentativo, dentro do tempo estipulado, e os valores de eficiência fermentativa foram aumentando do primeiro para o quarto ciclo, tanto para as canas não florescidas como para as florescidas, até atingirem valores considerados ótimos no último (Tabela 10). Os teores de potássio obtidos para mostos de cana de florescida, provavelmente, foram satisfatórios para que a levedura os utilizasse para seu desenvolvimento e manutenção (Tabelas 6 e 4).

\subsection{Acidez Volátil do Vinho}

Os dados de acidez volátil no vinho para cana não florescida e florescida são apresentados na Tabela 9.

Tabela 9. Resultados obtidos das determinações de Acidez Volátil expressos em mg de $\mathrm{CH}_{3} \mathrm{OOH} / 100 \mathrm{ml}$ de vinho.

\begin{tabular}{|c|c|c|c|c|c|c|c|c|}
\hline \multirow{3}{*}{ Ciclos } & \multicolumn{8}{|c|}{ ENSAIOS } \\
\hline & \multicolumn{2}{|c|}{ I } & \multicolumn{2}{|c|}{ II } & \multicolumn{2}{|c|}{ III } & \multicolumn{2}{|c|}{ IV } \\
\hline & NF & F & NF & $\mathbf{F}$ & NF & F & NF & F \\
\hline $1^{\circ}$ & 23 & 31 & 54 & 41 & 51 & 45 & 42 & 45 \\
\hline $2^{\circ}$ & 21 & 24 & 69 & 64 & 78 & 72 & 52 & 53 \\
\hline $3^{\circ}$ & 17 & 16 & 55 & 80 & 54 & 54 & 39 & 46 \\
\hline $4^{\circ}$ & 17 & 15 & 71 & 60 & 52 & 52 & 32 & 39 \\
\hline Média & 19 & 21 & 62 & 61 & 59 & 56 & 41 & 46 \\
\hline
\end{tabular}


Os valores obtidos mostraram variações de 17 a 78 para as canas não florescidas e de 15 a $80 \mathrm{mg}$ de $\mathrm{CH}_{3} \mathrm{COOH} / 100 \mathrm{ml}$ de vinho no caso de cana florescida. Pode-se observar que os dados não seguem uma evolução regular. Verifica-se pelas médias nos quatro ensaios, que os vinhos para canas florescidas apresentaram ora valores inferiores, ora superiores aos vinhos para cana não florescida.

Em comparação com valores de acidez volátil do mosto, Tabela 3, poderia-se afirmar que houve produção de acidez volátil durante o processo de fermentação, porém tal conteúdo formado não atuou como inibidor do processo fermentativo uma vez que se obteve elevada viabilidade celular (Tabela 4).

\subsection{Eficiência Fermentativa}

Os dados obtidos para a eficiência de fermentação e seus valores médios para os 4 ensaios são apresentados na Tabela 10 . 
Tabela 10. Resultados obtidos para Eficiência Fermentativa (\%).

\begin{tabular}{c|cc|cc|cc|cc}
\hline \multirow{2}{*}{ Ciclos } & \multicolumn{7}{|c|}{ ENSAIOS } \\
\cline { 2 - 10 } & \multicolumn{2}{|c|}{ I } & \multicolumn{2}{c|}{ II } & \multicolumn{2}{|c}{ III } & \multicolumn{2}{|c}{ IV } \\
\cline { 2 - 10 } & NF & F & NF & F & NF & F & NF & F \\
\hline $1^{\circ}$ & 79,22 & 76,70 & 82,25 & 78,58 & 86,66 & 84,24 & 79,43 & 80,54 \\
$2^{\circ}$ & 86,07 & 86,27 & 87,13 & 84,03 & 88,48 & 87,95 & 84,98 & 87,18 \\
$3^{\circ}$ & 87,53 & 89,94 & 89,51 & 89,68 & 92,26 & 91,79 & 86,07 & 89,88 \\
$4^{\circ}$ & 91,66 & 92,58 & 91,79 & 92,74 & 92,31 & 92,56 & 91,51 & 92,30 \\
\hline Média & 86,12 & 86,34 & 87,67 & 86,26 & 89,93 & 89,13 & 85,50 & 87,47 \\
\hline
\end{tabular}

As eficiências foram obtidas a partir dos valores de ART do mosto e dos graus alcoólicos do fermento e vinho, conforme demonstrado nas Tabelas 2 e 11. 
Tabela 11. Resultados obtidos para Grau Alcóolico do pé-de-cuba e vinho expressos em $\mathrm{ml} / 100 \mathrm{ml}$.

\begin{tabular}{|c|c|c|c|c|c|c|c|c|c|}
\hline \multirow{3}{*}{\multicolumn{2}{|c|}{ Ciclos }} & \multicolumn{8}{|c|}{ ENSAIOS } \\
\hline & & \multicolumn{2}{|l|}{ I } & \multicolumn{2}{|c|}{ III } & \multicolumn{2}{|c|}{ IIII } & \multicolumn{2}{|c|}{ IV } \\
\hline & & NF & F & NF & $\mathbf{F}$ & NF & F & NF & F \\
\hline \multirow[t]{2}{*}{$1^{\circ}$} & Pé & 0,00 & 0,00 & 0,00 & 0,00 & 0,00 & 0,00 & 0,00 & 0,00 \\
\hline & Vinho & 6,49 & 6,25 & 6,72 & 6,41 & 6,72 & 6,64 & 6,64 & 6,64 \\
\hline \multirow[t]{2}{*}{$2^{\circ}$} & Pé & 3,46 & 3,03 & 3,53 & 3,46 & 3,53 & 3,46 & 3,53 & 3,03 \\
\hline & Vinho & 8,08 & 8,08 & 7,99 & 7,83 & 8,08 & 7,83 & 8,16 & 8,08 \\
\hline \multirow[t]{2}{*}{$3^{\circ}$} & Pé & 4,32 & 4,10 & 4,46 & 4,61 & 4,10 & 4,32 & 4,32 & 4,10 \\
\hline & Vinho & 8,48 & 8,56 & 8,48 & 8,48 & 8,56 & 8,56 & 8,64 & 8,89 \\
\hline \multirow[t]{2}{*}{$4^{\circ}$} & Pé & 4,46 & 4,32 & 4,61 & 4,83 & 4,61 & 5,12 & 4,83 & 4,39 \\
\hline & Vinho & 8,89 & 8,89 & 8,56 & 8,64 & 8,48 & 8,89 & 8,80 & 8,80 \\
\hline
\end{tabular}

Os resultados encontrados variaram de 79,22 a 92,31 e de 76,60 a 92,74\% para as fermentações de mosto de caldo de cana não florescida e florescida respectivamente. Como pode-se observar pelos resultados dos ensaios, nos primeiros ciclos apresentaram valores mais baixos de eficiência do que os demais. Isto poderia ser consequência da adaptação das células ao meio fermentativo ou pelo consumo de açúcar pelas leveduras para formação de outros produtos que não o etanol, já que valores de 
açúcares redutores residuais totais foram baixos (Tabela 12), o que vem de encontro ao relatado por HARRISON \& GRAHAM (1970) e BEVERES \& VERACHTERT (1970). A medida que os ciclos foram se desenvolvendo a tendência foi de aumentar as eficiências até atingir valores considerados 6 timos no $4^{\circ}$ ciclo.

Tabela 12. Resultados obtidos das determinações de ARRT expressos em g de açúcar invertido/litro do mosto.

\begin{tabular}{|c|c|c|c|c|c|c|c|c|}
\hline \multirow{3}{*}{ Ciclos } & \multicolumn{8}{|c|}{ ENSAIOS } \\
\hline & \multicolumn{2}{|c|}{ I } & \multicolumn{2}{|c|}{ II } & \multicolumn{2}{|c|}{ III } & \multicolumn{2}{|c|}{ IV } \\
\hline & NF & F & NF & F & NF & F & NF & $\mathbf{F}$ \\
\hline $1^{\circ}$ & 0,51 & 0,32 & 0,17 & 0,29 & 0,01 & 0,03 & 0,13 & 0,05 \\
\hline $2^{\circ}$ & 0,36 & 0,26 & 0,41 & 0,44 & 0,17 & 0,07 & 0,09 & 0,13 \\
\hline $3^{\circ}$ & 0,54 & 0,35 & 0,28 & 0,50 & 0,17 & 0,25 & 0,24 & 0,29 \\
\hline $4^{\circ}$ & 0,65 & 0,41 & 0,52 & 0,54 & 0,14 & 0,11 & 0,20 & 0,19 \\
\hline Média & 0,51 & 0,33 & 0,34 & 0,44 & 0,12 & 0,11 & 0,16 & 0,16 \\
\hline
\end{tabular}


Outra explicação para os primeiros ciclos apresentarem eficiências menores em relação aos demais, poderia ser dada pelo possível consumo de açúcar para formação de células, conforme CASEY et al. (1984) e AMORIM et al. (1985) e que segundo STUPIELLO \& HORII (1982) pode ocorrer o desvio de 2 a $10 \%$ do açúcar total para produção de células de levedura.

Pelo exame das médias encontradas, verifica-se que não houve uma tendência definida para o comportamento entre as canas não florescidas e florescidas, isto é, ora para não florescida o valor foi maior, ora para a florescida foi mais elevado (Figura 6). Não houve diferença que pudesse ser considerada com relação ao desempenho fermentativo. O grau alcoólico do primeiro para o quarto ciclo sempre aumentou, tanto para as canas não florescidas como para as florescidas. Os teores alcoólicos em cada ciclo foram aumentando ocasionando de maneira geral uma queda das viabilidades (Tabela 6), o que está de acordo com a colocação de PASCUAL et al. (1987). 


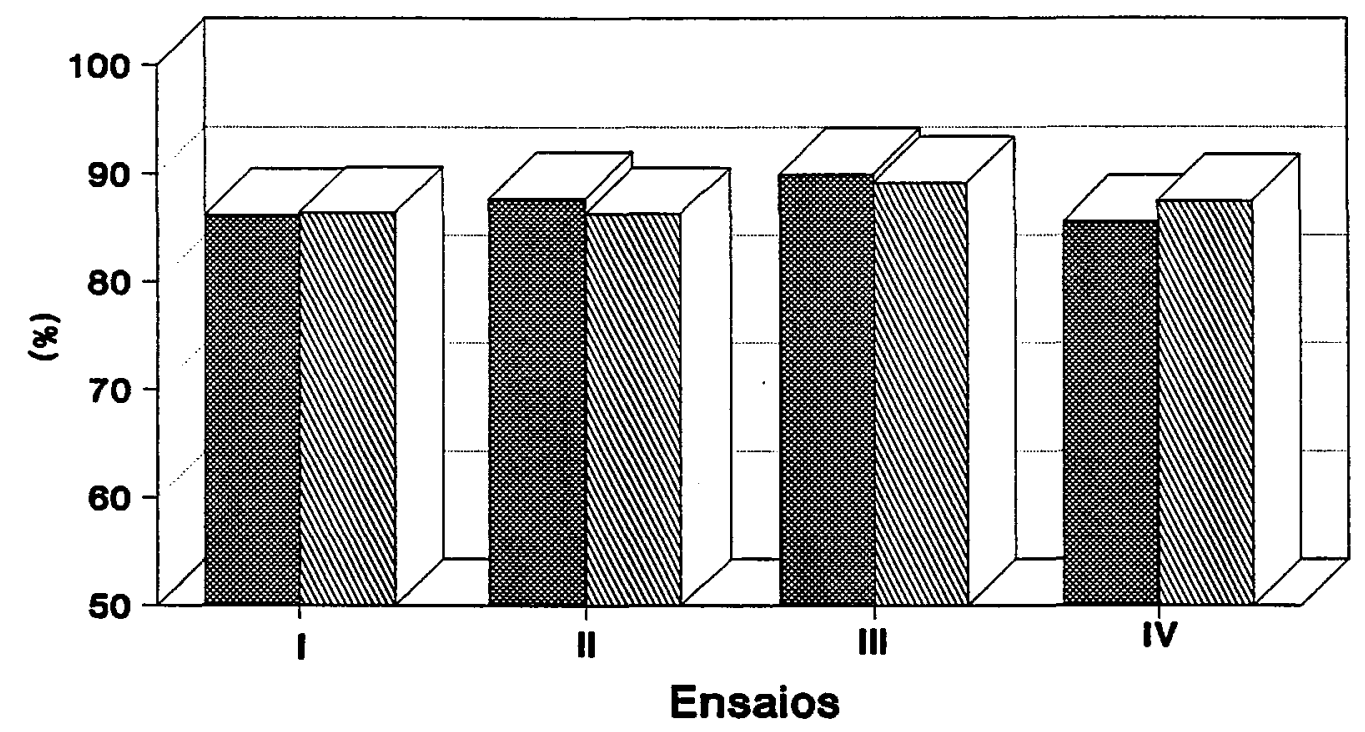

NF F

Figura 6. Médias de Eficiência Fermentativa dos ensaios com mosto de caldo de colmos de cana-de-açúcar não florecida e florecida. 


\section{CONCLUSÕES}

- O florescimento não afetou negativamente as características da matéria-prima.

- Os teores de Açúcares Redutores Totais (ART) foram da mesma ordem para os mostos de caldo de colmos de cana-de-açúcar não florescida e florescida

- Os teores de nitrogênio, fósforo e potássio foram menores para os mostos de caldo de colmos de cana florescidas.

- O florescimento da cana-de-açúcar não afetou a eficiência fermentativa nas condições do experimento. 


\section{REFERÊNCIAS BIBLIOGRÁFICAS}

ALEXANDER, A.G. Flowerind. In: ___ Sugarcane Physiology. A comprehensive study of the Saccharum sour-se-to-sink system, New York, Elsevier, 1973. cap.14., p. 523-72.

ALEXANDER, A.G. Intensive flowering performance and regulation in high-growth sugarcane. In: THE 1991 INTER-AMERICAN SUGAR CANE SEMINAR, Miami, 1991. Proceedings. Rio Piedras, AES-UPR Departament of Agronomy an Soils, 1991. p.1-23.

ALLAM, A.I.; NOUR, A.H.; FAYED, T.A. Effect on nitrogen and moisture on sugarcane flowering. In: CONGRESS OF THE INTERNATIONAL SOCIETY OF SUGar CANA TECHNOlOGISTS, 16, São Paulo, 1977. Proceedings. São Paulo, Impress, 1977. v.2., p. 875-92.

ALMEIDA, J,R, de; VALSECHI, O.; GOMES, F.P. O florescimento da cana-deaçúcar. Anais da Escola Superior de Agricultura "Luiz de Queiroz", Piracicaba, 2: 49-114, 1945. 
AMERINE, M.A. \& OUGH, C.S. Wine and must analysis. New York, John Wiley \& Sons, New York. 1974. 121p.

AMIN, G.; EYNED, E. Van den; VERACHTERT, H. Determination of by-products formed during the ethanolic fermentation, using batcth and immobilized cell systems of Zymomonas mobilis and Saccharomyces albanus. European Journal of Applied Microbiology and Biotechnology, New York, 18: 1-5, 1983.

AMORIM, H.V. Introdução à bioquímica da fermentação alcóolica, Araras, PLANALSUCAR, 1977. 95p.

AMORIM, H.V.; ZAGO, E.A.; OLIVEIRA, A.J. Novos métodos para controle da fermentação alcóolica. São Paulo, Sociedade Brasileira de Microbiologia, 1982. $57 p$.

AMORIM, H.V. Nutrição mineral de levedduras. Aspectos teóricos e práticos. In: SEMANA DE FERMENTAÇÃo AlCóoliCA, 4, Piracicaba. Anais. Piracicaba, ESALQ/STAB, 1985. p.44-8.

ANDRIETTA, S.R. \& CARUSO, J.G.B. Determinação de açúcares redutores residuais. Piracicaba, ESALQ/Depto de Ciência e Tecnologia Agroindustrial, 1992 (no Prelo) 
ARANETA JR, R. The effect of tasseling on yield. Sugarland, Bacolod City, 4/5: 20$2,1968$.

ARCENEAUX, G. Flowering in sugarcane. In: CONGRESS OF THE INTERNATIONAL SOCIETY OF SUGAR CANA TECHNOLOGISTS, 12, Puerto Rico, 1965. Proceedings. Amsterdam, Elsevier, 1967. p. 780-4.

AULD, D.S.; ATSUYA, J.; CAMPINO; VALENZUELO, P. Yeast RNA polymerase I. A eukaryotic zinc metalloenzyme. Biochemical and Biophysical Research Communications, New York, 69: 548-54, 1976.

AZZI, G.M. Cana-de-açúcar: florescimento. Revista de Tecnologia das Bebidas, São Paulo, 19(1): 33-8, 1967.

BARBIERI, V.; MANIERO, M.A.; MATSUOKA, S. O florescimento da cana-deaçúcar e sua implicações no manejo agrícola. In: CONGRESSO NACIONAL DA SOCIEDADE DOS TÉCNICOS AÇUCAREIROS E ALCOOLEIROS DO BRASIL

- STAB, 3., São Paulo, 1984. Anais. Piracicaba, STAB, 1984, p.273-6. 
BARBIERI, V. \& LOPES, J.J.C. Metodologia para estimativa dos efeitos do florescimento na qualidade agroindustrial da cana-de-açúcar (var. NA56-79). In: CONGRESSO NACIONAL DA SOCIEDADE DOS TÉCNICOS AÇUCAREIROS DO BRASIL, 4., Olinda, 1987. Anais. Piracicaba, STAB, 1987, p.376-9.

BARTLEY, W. \& BROOMHEAD, U. Properties of yeasts grown anaerobically in media limiting in potassium. Biochemical Journal, London, 121: 461-7, 1971.

BEVERES, J. \& VERACHTERT, H. Synthesis of higher alcohols in the genus Zymomonas. Journal of the Institute of Brewing, London, 82: 35-40, 1976.

BROWN, I.A. \& CHAMBERS. G.M. El control de la floracion de caña puede aumentar los rendimentos de azucar. Boletin Azucareiro Mexicano, México, 1970. p. 41-8.

CACHOT, T.; MÜLLER, M.; PONS, M.N. Kinetics of volateis metabolites during alcoholic fermentation of cane molases by Saccharomyces cerevisiae. Applied Microbiology and Biotechnology, Berlin, 35: 450-4, 1991. 
CASEY, G,P; MAGNUS, C.A.; INGLEDEW, W.M. Hight-growth brewing: effect of nutrition on yeast composition fermentation ability, and alcohol production. Applied and Environmental Microbiology, Baltimore, 48(3): 639-46, 1984.

CASTRO, P.R.C. Controle da florescência da cana-de-açúcar. Álcool \& Açúcar, São Paulo, 4(17): 44-9, 1984.

CÉSAR, M.A.A.; DELGADO, A.A.; GABAY, L.C. Aumento do nível de amido e de potássio no caldo da cana decorrente da aplicação sistemática de vinhaça ao solo. Brasil Açucareiro, Rio de Janeiro, 92(1): 24-9, 1978.

CLEMENTS, H.F. \& AWADA, M. Experiments on the artificial induction of flowering in sugarcane. In: CONGRESS OF THE INTERNATIONAL SOCIETY OF SUGAR CANA TECHNOLOGISTS, 12, Puerto Rico, 1965. Proceedings. Amsterdam, Elsevier, 1967. 户. 795-812.

COLEMAN, R.E. Fatores involved in the flowering of sugarcane (Saccharum spp.). In: CONGRESS OF THE INTERNATIONAL SOCIETY OF SUGAR CANA TECHNOLOGISTS, 10, Havai, 1959. Proceedings. Amsterdam, Elsevier, 1960. p. $805-14$. 
COLEMAN. R.E. Physiology of flowering in sugarcane. In: CONGRESS OF THE INTERNATIONAL SOCIETY OF SUGAR CANA TECHNOLOGISTS, 13, Taiwan, 1968. Proceedings. Amsterdam, Elsevier, 1969. p. 992-1000.

COLETI, J.T.; LORENZETTI, J.M.; FREITAS, P.G.R.; CORBINI, J.L.L WALDER, L.A.M.; CAMPONEZ NETO, A. Inibição de florescimento pelo uso do ethephon e sua influência na biomassa. In: CONGRESSO NACIONAL DA SOCIEDADE DOS TÉCNICOS AÇUCAREIROS DO BRASIL, 3., São Paulo, 1984. Anais. São Paulo, STAB, 1984, p.348-51, 1984.

CYZEWSKI, G.R. \& WILKE, C.R. Rapid ethanol fermentation using vaccum cell recycle. Biotechnology and Bioengieneering, New York, 19: 1125-43, 1977.

DE MARTIN, V.F. \& OLIVEIRA, A.J. Efeito da remoção de células sobre o rendimento da fermentação alcoólica por leveduras. Revista de Microbiologia, São Paulo, 22(2): 170-8, 1981.

DHAMIJA, S.S.; DAHIYA, D.S.; TAURO, P. Effect of molasses composition on ethanol fermentation. Journal of Food Science and Technology, Mysore, 23(3): $162-4,1986$. 
DOMBEK, K.M. \& INGRAM, L.O. Magnesium limitation and its role in apparent toxicity of ethanol during yeast fermentation. Applied and Environmental Microbiology, Washington, 52(5): 975-81, 1986.

EGUCHI, S.Y. Leveduras: fisiologia e bioquímica. In: EGUCHI, S.Y. et al. Pontos críticos microbiológicos em usinas de açúcar e álcool, Campinas, Fundação Tropical de Pesquisas "André Tosello", 1989. p.1-16.

EVANS, H.; BATES, J.F. Some observation on the incidence and prevention of flowering of sugar cane in Guyano. In: BRITISH WEST INDIES SUGAR TECHNOLOGISTS, Guyana, 1966. Proceedings. p. 279-90.

FAUCONNIER, R. \& BASSEREAU, D. Floración. In: . La caña de azucar, Barcelona, Blume, 1975. p. 20-1.

FERNANDES, A.J. Florescimento da cana-de-açúcar. In: - Manual da canade-açúcar. Piracicaba, Livroceres, 1984. p.110-1.

FOGLIATA, F.A. \& MORIN, D.M. Calid. industrial de caña de azucar florecida. Revista Industrial y Agricola de Tucumám, Tucumán, 52(1): 49-60, 1975. 
FORBES, R.M. Studies of zinc metabolism. In: ALBANESE, A.A., ed. Newer methods of nutritional biochemistry, New York, Academic Press, 1967. v.3., cap.7., p.339-64.

GEERLIGS, H.C.P. Cane sugar and its manufacture. 2 ed., New York, Van Nostrand, 1924. 324p.

GLÓRIA, N.A. da; RODELLA, A.A. Métodos de análise quantitativa inorgânica em caldo de cana-de-açúcar; vonhaça e melaço - I. Determinação de cálcio, magnésio, potássio, enxofre e fósforo em um mesmo extrato. Anais da Escola Superior de Agricultura "Luiz de Queiroz", Piracicaba, 29: 5-17, 1972.

GOMOI, G. A modification for the colorimetric phosphorus determination for use with photoeletric colorimeter. Journal of Laboratory and Clinical Medicine, St. Louis, 27: 955-60, 1942.

GUTIERREZ, L.E. Estudo comparativo da fermentação alcóolica por linhagens de Saccharomyces cerevisiae e Saccharomyces uvarum, Piracicaba, 1989. 160p. (Livre Docência - Escola Superior de Agricultura "Luiz de Queiroz" - USP).

GUTIERREZ, L.E. Tópicos de bioquímica de levedura, Piracicaba, ESALQ/Depto de Química, 1994. 103p. 
HARRISON, J.S.S GRAHAM, J.C.J. Yeasts in destilary practice. In: ROSE, A.H. \& HARRISON, J.S., ed. The Yeasts, New York, Academic Press, 1970. v.3., cap.6, p. 283-348.

HENRY, S.A.; ATKINSON, K.; KOLAT, A.; CULBERTSON, M.R. Growth and metabolism of inositol-starved Saccharomyces cerevisiae. Journal of Bacteriology, Baltimore, 130(1): 472-84, 1977.

HERNANDEZ, J.A.L. The quality of flowering cane. Sugar y Azucar, New York, 60(2): 41-2, 1965.

HOMMES, F.A. Effect of glucose on the level of glycolytic enzymes in yeast. Archives of Biochemistry and Biophysics, New York, 114: 231-3, 1966.

HUMBERT, R.P. Control of flowering, In: . The growing of sugar cane, Amsterdam, Elsevier, 1963. cap.8, p. 458-97.

HUMBERT, R.P.; LIMA, G.M.; GOVEAS, J. Tassel control progress with reglone in the mexican sugar industry. In: CONGRESS OF THE INTERNATIONAL SOCIETY OF SUGAR CANA TECHNOLOGISTS, 13, Taiwan, 1968. Proceedings. Amsterdam, Elsevier, 1969. p. 462-7. 
IAIA, A.M.; LEE, T.S.G.; MATSUOKA, S.; PARAZZI, C.; FERRARI, S.E.; BARBIERI, V. efeito do florescimento no rendimento e na qualidade tecnológica da cana-de-açúcar. Brasil Açucareiro, Rio de Janeiro, 103(4,5/6): 18-25, 1985.

INTERNATIONAL COMMISSION FOR ANALYSIS - ICUMSA. Sugar analysis; Official and testative methods recommended by the international commission for uniform methods of sugar analysis. Peterbonough, 1979, 265 p.

JONES, R.P.; PAMMENT, N.; GREENFIELD, P.F. Alcohol fermentation by yeasts. The effect of environmental and other variables. Process Biochemistry, London, 16(3): 42-9, 1981.

JONES, R.P. Effect of the relative concentration of ion species on yeasts growth and ethanol production. Process Biochemistry, London, 21(6): 183-7, 1986.

JULIEN, M.H.R.; DELAVEAU, P.; SOOPRAMANIEN, G.C.; MARTINÉ, J.F. Age, time of harvest and environment as factors influencing differences in yield between flowering and vegetative canes. In: CONGRESS OF THE INTERNATIONAL SOCIETY OF SUGAR CANA TECHNOLOGISTS, 16, São Paulo, 1977. Proceedings. São Paulo, Impress, 1977. v.2., p. 1771-90. 
KENYON, C.P.; PRIOR, B.A.; VUUREN, H.J.J. Van. Water relations of ethanol fermentation by Saccharomyces cerevisiae: glycerol production under solute strees. Enzyme and Microbial Technology, Guilford, 8: 461-4, 1986.

LAFON-LAFOURCADE, S. \& PEYNAULD, E. Sur les taux des acids cétoniques formés au cours de la fermentation alcoolique. Annales de L'Institut Pasteur, Paris, 110: 766-78, 1966.

LAFON-LAFOURCADE, S.; GENEIX, C.; RIBEREAU-GAYON, P. Inhibition of alcoholic fermentarion of grape must by fatty acids produced by yeasts ghosts. Applied and Environmental Microbiology, Baltimore, 47: 1246-9, 1984.

LAFON-LAFOURCADE, S. \& RIBEREAU-GAYON, P. Developments in the microbiology of wine production. Progress in Industrial Microbiology. Amsterdam, 19: 1-45, 1984.

LANE, J,H, \& EYNON, L. Volumetric determination of reducing sugars by means of fehling's solution with methilene blue indicator. International Sugar Journal, West Glamorgan, 25(289): 143-9. 1923. 
LEE, T.S.G.; SILVA, M.R.; IAIA, A.M.; MAGALHÃES, P.M. de.; PERUSSI, E.M. Controle de florescimento da cana-de-açúcar através do emprego de produtos químicos. STAB. Açúcar, Álcool e Subprodutos, Piracicaba, 3(3): 17-21, 1985.

LEHNINGER, A. Biochemistry. 2.ed. Work Publ., 1970. 833p. New York.

LETOURNEAU, F. \& VILLA, P. Saccharomyces yeast growth on beet molasses: effect of substrate concentration on alcohol toxicity. Biotechology Letters, Kew, 9: 53-8, 1987.

LEWIS, M.J. \& PHAFF, H.J. Release of nitrogenous substances by brewer's yeast. III. Shock excretion of aminoacids. Journal of Bacteriology, Baltimore, 87(6): 1389-96, 1964.

MACHADO JR, G.R. Melhoramento da cana-de-açúcar. In: PARANHOS, S.B. coord. Cana-de-açúcar cultivo e utilização, Campinas, Fundação Cargill, 1987. v.1., p.165-86.

MAIORELLA, B.; WILKE, C.R.; BLANCH, H.W. Alcohol production and recovery. Advances in Biochemical Engineering, Berlin, 20: 43-92, 1981. 
MAIORELLA, B.; BLANCH, W.H.; WILCHE, C.R. By-product inhibition effects on ethanolic fermentation by Saccharomyces cerevisiae. Biotechnology and Bioengieneering, New York, 25: 103-21, 1983.

MAIORELLA, B.L. Ethanol. In: MOO-YONG, M. ed. Comprehensive biotechnology. Oxford, Pergamon Press, 1985. v.3., cap 43, p. 861-914.

MARTIN-LEAKE, H. The flowering of the sugar cane. International Sugar Journal, London, 48: 174-6, 1946.

GOSNELL, J.M. \& JULIEN, H.R. Variations in the effects of flowering on cane yield and quality. In: SUGARCANE RIPENER SEMINAR, Orlando, 1976. Proceedings. St. Louis, Monsanto Agricultural Products Company. 1976. p.2237.

MIOCQUE, J. Cana: os requisitos par ao florescimento. Revista de Tecnologia das Bebidas, 17(9): 40-2, 1965.

NABAIS, R.C.; CORREIA, I.S.; VIEGAS, C.A.; NOVAIS, J.M. Influence of calcium ion on ethanol tolerance of Saccharomyces bayanus and alcoholic fermentation by yeasts. Applied and Enviromental Microbiology, Washington, 54(10): 243946, 1988. 
NAGODAWITHANA, T.W.; CASTELLANO, C.; STEINKRAUS, K.H. Effect of dissolved oxygen, temperature, inicial cell count, and sugar concentration on the viability of Saccharomyces cerevisiae in "rapid fermentation". Applied Microbiology, Baltimore, 28(3): 383-91, 1974.

NAHAMUNI, I.; IYER, T.A..G.; RAMAMOORTHY, N.; RAJAN, S.D. Influence of manures and fertlizers on the quality constituints of sugar cane juice. Indian Sugar, Calcuttá, (22): 775-80, 1973.

NAVARRO, J.M. \& DURAND, G. Fermentation alcoolique: influence de la temperature sur l'accumulation d'alcool dans le cellules de levedure. Annales de L'Institute Pasteur Microbiologice, Paris, 129 B: 215-21, 1978.

NGANG, J.J.E.; LETOURNEAU, F.; VILLA, P. Alcoholic fermentation of beet molasses: effect of lactic acid on yeasts fermentation parameters. Applied Microbiology and Biotechnology, Berlin, 31: 125-8, 1989.

NICKELL, L.G. Chemical growth regulation in sugarcane. Outlook on Agriculture, Bracknell, 9(2): 57-60, 1976.

NOVAS variedades Copersucar. Boletim Técnico Ccopersucar, São Paulo, 1983. p. 18-57. 
NUNES JR, D.; GIACOMINIM G,; OLIVEIRA, A.A. Comparação do florescimento, isoporização e qualidade tecnológica em duas cariedades de cana-de-açúcar na presença de maturador. Boletim Técnico Copersucar, São Paulo, (20): 20-30, 1982.

O FLORESCIMENTO da cana-de-açúcar e consequências. Brasil Açucareiro, Rio de Janeiro, 38(10): 69-75, 1951.

PANCHAL, C.J.; TAVARES, F.C.A. Yeast strain selection for fuel ethanol production. In: PANCHAL, C.J. Yeast strain selection. New York, Marcel Deckker, 1990. cap.8, p.225-43.

PANJE, R.R. \& RAO, T.R. Prevention od flowering in sugarcane. Current Science, Bangalore, 30: 211-2, 1961. s.1.p.

PANJE, R.R. \& RAO, T.R.; SRIVASTAVA, K.K. Studies on the prevention of flowering in sugarcane. I. Effect od suppression of flowering by defoliation on the yield and juice-quality of cane. In: CONGRESS OF THE INTERNATIONAL SOCIETY OF SUGAR CANA TECHNOLOGISTS, 13, Taiwan, 1968. Proceedings. Amsterdam, Elsevier, 1969. p. 468-75. 
PANJE, P.R. Control of flowering can lead to increase yields of sugarcane. Lucknow, Indian Institute of Sugarcane Research, 1970. 3p.

PASCUAL, C.; ALONSO, A.; GARCIA, I.; ROMAY, C.; KOTYK, A. Effect of ethanol on glucose transport, key glycolytic enzymes, and proton extrusion in Saccharomyces crevisiae. Biotechnology and Bioengineering, New York, 32: 374-8, 1988.

PEREIRA, A.R.; BARBIERI, V.; MANIERO, M.A. Condicionamento alimentício da indução ao florescimento em cana-de-açúcar. STAB. Açúcar, Álcool e Subprodutos, Piracicaba, 4(6): 56-9, 1986.

PICKERELL, A.T.W. The influence of free alpha-amino nitrogen in sorghum beer fermentation. Journal of the Institute of Brewing, London, 92: 568-71, 1986.

PIERCE, J.S. Analysis committee measurement of yeast viability. Journal of the Institute of Brewing, Cambridge, 76(5): 442-3, 1970. 
PIRES, C.E.L.E.S. \& MELO, M.M. de. Estudo preliminar sobre a ocorrência do florescimento em cana-de-açúcar nas regiões canavieiras dos Estados de Pernanbuco e Rio Grande do Norte. In: CONGRESSO NACIONAL DA SOCIEDADE DOS TÉCNICOS AÇUCAREIROS DO BRASIL, 3, São Paulo, 1984. Anais. São Paulo, STAB, 1984, p.344-8.

PIRES, C.E.L.S.; BARBOSA, G.P.; FARIAS, S.O.; MELO, M.M. Influência da época de coheita na qualidade da variedade de cana-de-açúcar RB72454 florescido. In: CONGRESSO NACIONAL DA SOCIEDADE DOS TÉCNICOS AÇUCAREIROS E ALCOOLEIROS DO BRASIL - STAB, 4., Olinda, 1987. Anais. Piracicaba, STAB, 1987, p.379-82.

RAIBOW, C. Brewer's yeasts. In: ROSE, A.H. \& HARRISON, J.S., ed. The Yeasts, New York, Academic Press, 1970. v.3., cap.4, p.147-224.

RIBEIRO, F.J.; LOPES, J.J.C.; FERRARI, S.E. Complementação de nitrogênio de forma contínua no processo de fermentação alcóolica. Brasil Açucareiro, Rio de Janeiro, 105(1): 26-30, 1987.

RODELLA, A.A. \& FERRARI, S.E. A composição da vinhaça e sua aplicação como fertilizante na cana-de-açúcar. Brasil Açucareiro, Rio de Janeiro, 90(7): 6-13, 1977. 
ROTHSTEIN, A. \& DEMIS, C. The relation of the cell surface to metabolism by extracellular potassium. Archives of Biochemistry and Biophysis, New York, 44: 18-29, 1953.

RUAS, D.G.G.; LIMA FILHO, S.A.; BEZERRA, A.P.; MACIAS, P.R.R.; MORGADO, I.F. Principais variedades de cana-de-açúcar cultivadas no Brasil em 1981 e 1982. Saccharum, Piracicaba, 6(29): 30-9, 1983.

SÁ-CORREIA, I. Synergistic effect of ethanol, octanoic and decanoic acids on the kinetics and the activation in Saccharomices bayanus. Biotechnology and Bioengiencering, New York, 28(5): 761-3, 1986.

SALATA, J.C. \& FERREIRA, L.J. Estudo da interferência do florescimento nas qualidades agroindustrais de algumas variedades de cana-de-açúcar. Brasil Açucareiro, Rio de Janeiro, 90(6): 19-24, 1977.

SALATA, J.C.; FERREIRA, L.J; CASAGRANDE, A.A. Interferência do florescimento nas qualidades agroindustriais de algumas variedade comerciais de cana-de-açúcar (Saccharum spp.). Brasil Açucareiro, Rio de Janerio, 99(1): 45$55,1982$. 
SALTUKOGLU, A. \& SLAUGHTER, J.C. The effect of magnesium and calcium on yeast growth. Journal of the Institute of Brewing, London, 89(2): 81-3, 1983.

SCRUTTON, M.C.; YOUNG, M.R.; UTTER, M.F. Pyruvate caboxylase from backer's yeast. Presence of bound zinc. Journal of Biological Chemistry, Baltimore, 225(22): 6220-7, 1970.

SEMINÁRIO de Tecnologia Agronômica, 1., Piracicaba, 1982. Piracicaba. Copersucar, 1982. p. 17-64.

STEHLE, H. The principal agronomic apects of the flowering of sugar cane: growth, methods od cultivation, matutrity, deterioration, after arrowing, upper point of cutting. In: BRITISH WEST INDIES SUGAR TECHNOLOGISTS, Barbados, 1955a. Proceedings. p. 49-57.

STEHLE, H. Intensity and seasons at which sugar cane flowers in relation to the sucrose and glucose cotent abd the purity of juices. In: BRITISH WEST INDIES SUGAR TECHNOLOGISTS, Barbados, 1955b. Proceedings. p. 58-62.

STEVENINK, J. VAN \& ROTHSTEIN, A. Sugar transport and metal binding in yeast. Journal of General Physiology, Baltimore, 49: 235-46, 1965. 
STUPIELLO, J.P. \& HORII, J. Condução da fermentação alcóolica. Saccharum, Piracicaba, (17): 43-6, 1981.

STUPIELLO, J.P. \& HORRI, J. Fundo de dorna de fermentação: um fator de eficiência industrial. STAB. Açúcar, Álcool e Subprodutos, Piracicaba, 1(1): 34-6, 1982.

STUPIELLO, J.P. Considerações sobre a recirculação de substâncias na fermentação e destilação alcóolica. STAB, Açúcar, Álcool e Subprodutos, Piracicaba, 2(5): 35-7, 1984.

SUOMALAINEN, H \& AXELSON, E. Effect thiamine on the rate of fermentation of zymohexoses and of latose by baker's yeasts. Biochimica et Biophysica Acta, Amsterdam, 20: 315-8, 1956.

SUOMALAINEN, H. \& OURA, E. Yeast nutrition and solute uptake. In: ROSE, A.H. \& HARRISON, J.S., eds. The yeast. London, Academic Press, 1970. V.2., p. 3.

TANIMOTO, T. The press method of cane analysis. Hawaiian Planter's Record, Honolulu, 51(2): 133-150, 1965. 
TANIMOTO, T.; NICKELL, L.G. Field control of sugarcane flowering in Hawai with Diquat. In: CONGRESS OF THE INTERNATIONAL SOCIETY OF SUGAR CANA TECHNOLOGISTS, 12, Puerto Rico, 1965. Proceedings. Amsterdam, Elsevier, 1967. p. 113-17.

TREVELYAN, W.E. \& HARRISON, J.S. Studies on yeasts etabolism. 3. The intracellular level of pyruvate during yeast fermentation. Biochemical Journal, London, 57: 556-61, 1954.

TRIBOLI, E.R. De Ros. Determinação da concentração de leveduras por centrifugação. In: - Métodos análiticos para o acompanhamento da fermentação alcóolica, São Caetano do Sul, Instituto Mauá de Tecnologia, 1987.

VIEGAS, C.A.; ROSA, M.F.; SÁ-CORREIA, I.; NOVAIS, J.M. Inhibition of yeasts growth by octanoic and decanoic acids produced during ethanolic fermentation. Applied and Environmental Microbiology, Baltimore, 55(1): 21-8, 1989.

VILlELA, G.G.; BACILA, M.; TALTADI, H. Técnicas e experimentos de bioquímica, Rio de Janeiro, Guanabara Koogan, 1972. 552p.

VISURI, K. \& KIRSOP, B. Influence of $\mathrm{pH}$ and of selected cations on the fermentation of malto-triose. Journal of the Institute of Brewing, London, 76(4): 362-6, 1970. 
WADA, M.; KAKO, J.; CHIBATA, I. Continuous production of ethanol in high concentration using immobilized growing yeast cell. European Journal of Applied Microbiology and Biotechnology, New York, 11: 67-71, 1981.

WALSH, R.M. \& MARTIN, P.A. Growth of Saccharomyces cerevisiae and Saccharomyces uvarum in a temperature gradient incubator. Journal of the Institute of Brewing, London, 83: 167-72, 1977.

WANDZILAK, T.M. \& BENSON, R.W. Yeast RNA polymerase. III. A zinc metalloenzyme. Biochemical and Biophysical Research Communications, New York, 76: 247-52, 1977.

WIGGINS, L.F. No-azucares nitrogenados (los aminoácidos e las proteinas). In: HONIG, P. ed. Principios de tecnologia azucarera, México, Ed. Continental, 1969. v.1., p. 155-72.

WHITE, J. Yeasts technology, London, Chapman \& Hall, 1954. 432p.

ZAGO, E.A. Efeito da concentração de $\mathrm{N}, \mathrm{P}, \mathrm{Mg}$, Mn e $\mathrm{Zn}$ na multiplicação de leveduras industriais. Piracicaba, 1982. 125p. (Doutoramento - Escola Superior de Agricultura "Luiz de Queiroz"/USP). 